\title{
The Effect of the Arabic Syllabic Prosodic Features on the Production of English CV Sequences
}

\author{
Dr. Mohammad Anani \\ English Department, Petra University \\ PO. Box 852366, Amman, Jordan \\ Tel: 962-6-5814059 E-mail: manani@uop.edu.jo
}

Received: November 17, 2012 Accepted: February 10, 2013 Published: February 18, 2013

doi:10.5296/ijele.v1i1.3274 URL: http://dx.doi.org/10.5296/ijele.v1i1.3274

\begin{abstract}
The aim of this research is to investigate the effect of the Arabic minimal prosodic unit (the syllable) on the production of English L2 CV sequences. To study the influence of phonetic context upon a given segment and the overall effect the Arabic syntagmatic features on the Arab learner's ability to reorganize in terms of English patterns, samples of conversational exchanges of some native speakers of adult/child Jordanian Arabic were recorded over a two month period. The syllable patterns that regulate the phonological organization of the conversational exchanges were described.
\end{abstract}

To study the effect of the preceding and following consonants on the adjacent vowel sounds, two sets of consonantal contexts were examined: 'emphatic' vs. 'non-emphatic'.

The objectives of this study are the following:

(i) to identify prosodic features which span the internal structure of the Arabic word templates, e.g. the vocalic melody of frontness vs. backness

(ii) to explore the Arabic language-specific phonological constraints and to determine their effect on the production of English sound patterns

(iii) to study the Arabic templates which are similar in shape to English equivalents, because contrastive linguistics studies, to date, have so far focused on phonological negative interlingual transfer to the effective exclusion of positive interlingual transfer.

(vi) to demonstrate how English utterances are restructured so that the constituent syllables follow typical Arabic syllabication.

Keywords: effect, prosodic features, L2 sequences, conversational exchange 


\section{Introduction}

For decades, studies in contrastive linguistics have focused on phonological difficulties discussed in a phonemically oriented way. (See, for example, Lehn, Walter \& Slager: 1959; Stockwell, R.: 1965 and Lado, R.: 1957). To consider Arabic learners' difficulties in learning English from a phonemic perspective only would be inadequate, since the emphasis would be placed on paradigmatic aspects to the effective exclusion of syntagmatic considerations. A prosodic approach stresses features of phonetic form, simple or complex, which characterize or associated with more than one segment of a phonemic or quasi-phonemic kind. (See Robins, R. H.: 1957). It is the syllable that is the hub of the Arabic phonological organization. Prosodic features such as stress, quantity (length) and 'emphasis' can only be described in terms of the syllable.

The ways in which different types of syllables are relatively ordered in patterns and what prosodic features they are characterized by have a considerable effect on how L2 patterns are ordered. Contrastive linguistic studies have so far concentrated on segmental negative interlingual transfer to the effective exclusion of prosodic interlingual transfer. The objective has been to find out differences between L1 systems so that learning difficulties related to individual segments could be identified and overcome.

The corpus of material chosen is generally artificial based on Classical Arabic or 'introspective judgments. When analysis is based on naturally occurring utterances, which are acquired rather than learned, a shift of attention becomes necessary.

\section{Objectives}

The aim of this research is to investigate the effects of the Arabic prosodic features on the production of L2 English $\mathrm{CV}(\mathrm{C})(\mathrm{C})-\mathrm{CV}(\mathrm{C})(\mathrm{C})$ sequences.

The variables to be examined are:

(i) the effect of SL prosodic features ( $\mathrm{L} 1$ accentual patterns, stress) on L2 C- to $-\mathrm{V}$ articulation.

(ii) the effect of preceding consonant ('emphatic'/'non-emphatic')

(iii) the effect of following consonant ('emphatic'/'non-emphatic')

\section{Method}

For the investigation of the effect of the minimal prosodic unit (the syllable) on L2 CV sequences, samples of three conversational exchanges, (see Appendix), for some native speakers of adult/child Jordanian Arabic were recorded over a two month period. In the treatment of prosodic features of' 'frontness', 'backness' (Cf. Mitchell, Ibid ), consonant cluster and syllable types, reference is particularly made to the four year old exchanges. In order to determine which syllable of a given word is stressed, say the last syllable (ultimate), or the second syllable from the end (penultimate), or two syllables from the end (antepenultimate), the syllable pattern has to be determined. Arabic stress-placement is wholly dependent on the structure of a word in terms of its constituent syllable quantities: 


\section{Ml Macrothink}

Long, Short, or Medium. (Cf. Mitchell: 1961, p. 270). It is generally recognized that there are three types of syllables in the Arabic phonological system: (i) light or (short) syllables if they are of the form CV, (ii) intermediate or (medium) if they are of structure CVC and (iii) heavy or (long) syllables if they are of the form CVCC, CVV, CVVC (Mitchell 198 :21). The following sections deal with the most frequent accentual patterns, which occur in the conversational exchanges recorded. Cited examples are taken from naturally occurring Jordanian child to adult conversational exchange, (See Appendix) the structure of the word is represented in terms of the common sequences of CV elements (Cf. Allan, W.S.:1956).

\section{Word Accentual Patterns}

\subsection{Accentual Pattern 1: Conversational Exchange 1}

Disyllabic patterns with ultimate Long syllable: CVVC, CVCC, CVV: the ultimate syllable is the most prominent or stressed.

Table 1. Disyllabic patterns with ultimate long syllable.

\begin{tabular}{|c|c|c|c|}
\hline Word & Structure & Word & Structure \\
\hline /sua:1l 'question' & CV-CVVC & ba'šu:f 'I'll see' & CV-CVVC \\
\hline /kama:n/'more' & CV-CVVC & /9i'ne:n/ 'eyes' & CV-CVVC \\
\hline $9 a^{\prime}{ }^{\prime} a: n$ 'so that' & CV-CVVC & di'ne:n 'ears' & CV-CVVC \\
\hline mi'la:d 'birthday' & CV-CVVC & $b i^{\prime} d u: n$ 'without' & CV-CVVC \\
\hline bil'be:t 'at home' & CVC-CVVC & zaHla?t' 'I slipped' & CVC-CVCC \\
\hline ?a9'ma:1 'business' & CVC-CVVC & fan'na:n 'artist' & CVC-CVVC \\
\hline$b i{ }^{\prime} S i: r \quad$ 'it can be' & CV-CVVC & fhimt 'I understood' & $\mathrm{CCVCC}$ \\
\hline ?ad'de:š 'how much & CVC-CVVC & $\mathrm{d} a^{\prime} r a b t \quad$ 'I hit' & CV-CVCC \\
\hline$b i^{\prime} 3 i: b \quad$ 'he brings' & CV'CVVC & $? a-' k a l t$ & $\mathrm{CV}-\mathrm{CVCC}$ \\
\hline
\end{tabular}

\subsection{Accentual Pattern 2}

Disyllabic patterns in which the penultimate is intermediate, i.e. $\mathrm{CV}, \mathrm{CVC}$ : the penultimate is stressed.

Table 2. Disyllabic patterns in which the penultimate is intermediate.

\begin{tabular}{|l|l|l|l|l|l|}
\hline Word & Structure & Word & Structure & Word & Structure \\
\hline $\begin{array}{l}\text { ? } \begin{array}{l}\text { 'th'ki } \\
\text { 'talk' }\end{array} \\
\text { 'ruHtu 'go' }\end{array}$ & CVC-CV & 'halla? 'now' & CVC-CVC & 'mama 'mummy' & CVV-CV \\
\hline $\begin{array}{l}\text { 'ya9ni' I } \\
\text { mean' }\end{array}$ & $\begin{array}{l}\text { CVC-CV } \\
\text { ask' }\end{array}$ & 'Tayyib 'O.K.' & CVC-CVC & '9a:di normal' & CVV-CV \\
\hline & & & & 'ha:da 'this' & CVV-CV \\
\hline & & & & 'si:di ' granny" & CVV-CV \\
\hline & & & & 'Su:ra' picture' & CVV-CV \\
\hline 'šwayye & CCVC-CV & 'biddak 'you & CVC-CVC & 'sa:kin 'living & CVV-CV \\
\hline
\end{tabular}




\begin{tabular}{|c|c|c|c|c|c|}
\hline little' & & want' & & & $\mathrm{C}$ \\
\hline 'ka9ke 'cake' & $\mathrm{CVC}-\mathrm{CV}$ & '9umrak"ever' & CVC-CVC & 'wa:rid' 'input' & $\begin{array}{l}\mathrm{CVV}-\mathrm{CV} \\
\mathrm{C}\end{array}$ \\
\hline & & & & mba:riH"yesterday & $\begin{array}{l}\text { CCVV-C } \\
\text { VC }\end{array}$ \\
\hline & & & & ša:Tir'good boy' & $\mathrm{CVV}-\mathrm{CV}$ \\
\hline & & & & 'd3a:riH 'hurting' & CVV-CV \\
\hline & & & & 'xa:lid 'for ever' & $\begin{array}{l}\mathrm{CVV}-\mathrm{CV} \\
\mathrm{C}\end{array}$ \\
\hline 'hassa.now. & CVC-CV & $\begin{array}{l}\text { 'tinzal'get } \\
\text { down' }\end{array}$ & CVC-CVC & Sa:di $r$ 'out' & $\begin{array}{l}\mathrm{CVV}-\mathrm{CV} \\
\mathrm{C}\end{array}$ \\
\hline "tsawwi 'do' & $\mathrm{CCV}-\mathrm{CV}$ & $\begin{array}{l}\text { 'biTla } \\
\text { 9'appears' }\end{array}$ & CVC-CVC & 'walad' boy' & $\mathrm{CV}-\mathrm{CVC}$ \\
\hline $\begin{array}{l}\text { 'Hilwe } \\
\text { 'sweet' }\end{array}$ & CVC-CV & 'tif?a9 & CVC-CVC & 'balad' country' & CVCVC \\
\hline $\begin{array}{l}\text { 'xamse } \\
\text { 'five' }\end{array}$ & $\mathrm{CVC}-\mathrm{CV}$ & $\begin{array}{l}\text { 'tudrus } \\
\text { 'study' }\end{array}$ & CVC-CVC & 'qalam 'pencil' & $\mathrm{CV}-\mathrm{CVC}$ \\
\hline $\begin{array}{lc}\text { 'biddi } & \text { 'I } \\
\text { want' } & \\
\end{array}$ & $\mathrm{CVC}-\mathrm{CV}$ & 'tisbaH 'swim' & CVC-CVC & & \\
\hline $\begin{array}{l}\text { 'zayyo 'like } \\
\text { it' }\end{array}$ & $\mathrm{CVC}-\mathrm{CV}$ & 'yiTla9 'go up' & CVC-CVC & & \\
\hline $\begin{array}{l}\text { 'Safra } \\
\text { 'yellow' }\end{array}$ & $\mathrm{CVC}-\mathrm{CV}$ & $\begin{array}{l}\text { 'kulhum'all of } \\
\text { them' }\end{array}$ & CVC-CVC & & \\
\hline $\begin{array}{l}\text { ?inte } \\
\text { 'you' }\end{array}$ & $\mathrm{CVC}-\mathrm{CV}$ & $\begin{array}{l}\text { 'bti9raf' he } \\
\text { knows }\end{array}$ & CVC-CVC & & \\
\hline 'halla really' & $\mathrm{CVC}-\mathrm{CV}$ & $\begin{array}{l}\text { 'ba9raf 'I } \\
\text { know' }\end{array}$ & CVC-CVC & & \\
\hline $\begin{array}{l}\text { 'marra } \\
\text { 'once' }\end{array}$ & CVC-CV & $\begin{array}{l}\text { bitHib 'you } \\
\text { like' }\end{array}$ & CVC-CVC & & \\
\hline $\begin{array}{l}\text { 'šuftu ' I saw } \\
\text { it' }\end{array}$ & CVC-CV & $\begin{array}{l}b^{\prime} t i H D a r^{\prime} \text { you } \\
\text { come' }\end{array}$ & CVC-CVC & & \\
\hline 'Hiffe 'edge' & CVC-CV & $\begin{array}{l}\text { 'tištri' you } \\
\text { buy' }\end{array}$ & $\begin{array}{l}\mathrm{CVCC}-\mathrm{CC} \\
\mathrm{VC}\end{array}$ & & \\
\hline $\begin{array}{l}\text { 'D3alTa } \\
\text { 'stroke' }\end{array}$ & CVC-CV & '?išta 'winter' & CVC-CV & & \\
\hline '?illi 'which' & CVC-CV & 'marra 'once' & $\mathrm{CVC}-\mathrm{CV}$ & & \\
\hline $\begin{array}{ll}\text { 'tiHki 'you } \\
\text { talk' }\end{array}$ & $\mathrm{CVC}-\mathrm{CV}$ & 'baHki'I talk' & $\mathrm{CVC}-\mathrm{CV}$ & & \\
\hline $\begin{array}{l}\text { '9amti 'my } \\
\text { aunt' }\end{array}$ & CVC-CV' & 'hayfa'Hayfa' & $\mathrm{CVC}-\mathrm{CV}$ & & \\
\hline
\end{tabular}




\subsection{Accentual Pattern 3}

Trisyllabic patterns in which both ultimate and penultimate are short; stress falls on the antepenultimate.

Table 3. Trisyllabic patterns in which both ultimate and penultimate are short.

\begin{tabular}{|l|l|}
\hline Word & Structure \\
\hline 'madras 'school' & CVC-CV-CV \\
\hline
\end{tabular}

\subsection{Accentual Pattern 4}

Monosyllabic patterns with long V-element, or with a final - $\mathrm{CC}$ sequence are made prominent.

Table 4. Monosyllabic patterns with long V-element, or with final-CC sequence.

\begin{tabular}{|c|c|c|c|c|c|c|c|c|c|}
\hline Word & Structure & Wd. & St. & Wd. & St. & Wd. & St. & Wd. & St. \\
\hline 'we:n'where' & CVVC & $\begin{array}{ll}\text { šuft' } & \text { I } \\
\text { saw', } & \end{array}$ & $\mathrm{CVCC}$ & yi: & CVV & $\begin{array}{l}\text { kam 'how } \\
\text { much' }\end{array}$ & $\mathrm{CVC}$ & $\mathrm{u}$ & $\mathrm{V}$ \\
\hline '?e:š 'what' & CVVC & $\begin{array}{l}\text { 'nzilt } \\
\text { 'stepped } \\
\text { down' }\end{array}$ & $\mathrm{CCVC}$ & ?e: & CVV & ma9 & CVC & $\mathrm{m}$ & $\mathrm{C}$ \\
\hline 'he:k 'this & CVVC & 'kunt & CVCC & '?a: & $\mathrm{CVV}$ & zay & $\mathrm{CVC}$ & $? \mathrm{u}$ & $\mathrm{CV}$ \\
\hline 'le:š 'why' & CVVC & 'bass & CVCC & 'la: & $\mathrm{CVV}$ & ?aw & $\mathrm{CVC}$ & šu & $\mathrm{CV}$ \\
\hline 'ki:f 'how' & CVVC & 'SaHH & CVCC & 'mu: & $\mathrm{CVV}$ & bas & $\mathrm{CVC}$ & fi & $\mathrm{CV}$ \\
\hline 'Tabb 'but' & $\mathrm{CVCC}$ & šu: & CVV & $\begin{array}{l}\text { hum' } \\
\text { they' }\end{array}$ & $\mathrm{CVC}$ & & & & \\
\hline 'zGi:r'small' & CCVVC & zift 'tar' & CVCC & 'ya & $\mathrm{CVV}$ & la?'no' & CVC & & \\
\hline 'be:t 'house' & CVVC & $\begin{array}{l}\text { talt } \\
\text { 'three' }\end{array}$ & CVCC & $\begin{array}{l}\text { 'fi: } \\
\text { 'in' }\end{array}$ & $\mathrm{CVV}$ & & & & \\
\hline min 'from' & CVC & & & & & & & & \\
\hline 'mi:n'who' & CVVC & '19ibt & CCVCC & 'hai & $\mathrm{CVV}$ & $\mathrm{Tab}$ & $\mathrm{CVC}$ & & \\
\hline '9i:d & CVVC & $\begin{array}{l}\text { '9ind } \\
\text { 'at' }\end{array}$ & CVCC & & & & & & \\
\hline 'ke:f 'how' & CVVC & 'smi9t & $\mathrm{CCVCC}$ & & & & & & \\
\hline 'ka:n 'was' & CVVC & & & & & & & & \\
\hline 'šlo:n 'how' & CCVVC & & & & & & & & \\
\hline 'Ti:r ‘fly’ & CVVC & & & & & & & & \\
\hline 'lo:n 'color' & CVVC & & & & & & & & \\
\hline 'na:r 'fire' & CVVC & & & & & & & & \\
\hline 'ma:t 'died' & CVVC & & & & & & & & \\
\hline
\end{tabular}




\section{Conversational Exchange (2)}

\subsection{Accentual Pattern 1}

Disyllabic Patterns with ultimate Long syllables (i.e. CVVC, CVCC, CVV); stress placement on the ultimate syllable.

Table 5. Disyllabic patterns with ultimate long syllables.

\begin{tabular}{|c|c|c|c|}
\hline Word & Structure & Word & Structure \\
\hline ?a'za:z 'glass' & CV-CVVC & baT'fi:h 'turn off & CVC-CVVC \\
\hline mu'bail 'mobile' & CV-CVVC & duzda:n 'wallet' & CVC-CVVC \\
\hline ?a'šu:f 'I see' & CV-CVVC & $m a z^{\prime} b u: T$ 'correct' & CVC-CVVC \\
\hline$f u^{\prime} ? i: h \quad$ 'above it' & CV-CVVC & maw'3u:d 'present' & CVC-CVVC \\
\hline Ha'ra:m 'taboo' & CV-CVVC & $b i t^{\prime} 3 i: b$ 'he brings' & CVC-CVVC \\
\hline ?an'a:m 'I sleep' & CV-CVVC & ?ab'Ta:l 'heroes' & CVC-CVVC \\
\hline ra'ni:m 'Raniim' & CV-CVVC & saw'we:t 'I did' & CVC-CVVC \\
\hline 'ta9a:l 'come on' & CV-CVVC & mal'yo:n 'full up' & CVC-CVVC \\
\hline ?a'šu:f 'Isee' & $\mathrm{CV}-\mathrm{CVVC}$ & bil'be:t 'at home' & CVC-CVVC \\
\hline$h a^{\prime} d o: l$ 'those' & CVC-CVVC & banzi:n 'oil' & CVC-CVVC \\
\hline mila:d 'birthday' & CV-CVVC & bi33i:b 'it brings' & CVC-CVVC \\
\hline bi'Si:r 'may be & $C V-C V V C$ & Hilwa:t & CVC-CVVC \\
\hline ša?lu:b'upside down' & CVC-CVVC & $a d^{\prime} d e: \check{s}$ & CVC-CVVC \\
\hline
\end{tabular}

\subsection{Accentual Pattern 2}

Disyllabic patterns in which the penultimate is intermediate, i.e. $\mathrm{CV}, \mathrm{CVC}$, or stress falls on the penultimate.

Table 6. Disyllabic patterns in which the penultimate is intermediate.

\begin{tabular}{|l|l|l|l|l|l|}
\hline Word & $\begin{array}{l}\text { Structu } \\
\text { re }\end{array}$ & Word & Structure & Word & Structure \\
\hline 'buzbuT & $\begin{array}{l}\text { CVC-C } \\
\text { VC }\end{array}$ & 'walla 'really' & CVC-CVC & 'ma:ma'mum' & CVV-CV \\
\hline '?ul-tlak & $\begin{array}{l}\text { CVC-C } \\
\text { VC }\end{array}$ & 'hassa 'now' & CVC-CV & 'ba:ba'Daddy' & CVV-CV \\
\hline $\begin{array}{l}\text { '?aHsan } \\
\text { 'better' }\end{array}$ & $\begin{array}{l}\text { CVC-C } \\
\text { VC }\end{array}$ & 'biddu'wants & CVC-CV & "te:ta 'granny' & CVVCV \\
\hline 'bakzib 'I lie' & $\begin{array}{l}\text { CVC-C } \\
\text { VC }\end{array}$ & 'xaltu'aunt' & CVC-CV & 'ha:tu 'give' it' & CVV-CV \\
\hline 'til9ab'play' & $\begin{array}{l}\text { CVC-C } \\
\text { VC }\end{array}$ & ya9ni' that is' & CVC-CV & Ge:ru' another' & CVV-CV \\
\hline 'šuftak'saw & $\begin{array}{l}\text { CVC-C } \\
\text { VC }\end{array}$ & 'lamma'when' & CVCCV & 'ha:da 'this' & CVV-CV \\
\hline '3ibltlak & $\begin{array}{l}\text { CVC-C } \\
\text { VC }\end{array}$ & 'stanni'wait' & CCVCCV & 'ra:su his head' & CVV-CV \\
\hline
\end{tabular}




\begin{tabular}{|l|l|l|l|l|}
\hline & & & la:zim 'must' & CVV-CVC \\
\hline & & & 'da:nu' his ear' & CVV-CV \\
\hline & & & 'sa:9a 'watch' & CVV-CV \\
\hline & & & xa:lu'his uncle' & CVV-CV \\
\hline & & & 'ra:su 'his head' & CVV-CV \\
\hline & & & 'xa:lid eternal" & CVVCVC \\
\hline & & & ta:9it ' his' & CVVCVC \\
\hline & & & '9a:mir 'Amir' & CVV-CVC \\
\hline
\end{tabular}

\subsection{Accentual Pattern 3}

(i) Trisyllabic patterns in which both ultimate and penultimate are short; stress falls on the antepenultimate and (ii) patterns in which the penult is not short receives stress on the penult.

Table 7. Trisyllabic patterns in which both ultimate and penultimate are short

\begin{tabular}{|l|l|l|l|}
\hline Word '9ašara 'ten' & Structure & Word & Structure \\
\hline 9aša:nak 'for you' & CV-CV-CV 'they & $\begin{array}{l}\text { 'Ga-salu } \\
\text { washed' }\end{array}$ & \\
\hline
\end{tabular}

Trisyllabic patterns in which both ultimate and penultimate are short

\subsection{Accentual Pattern 4}

Monosyllabic patterns with long V-element, or with a final -CC sequence are prominent:

Table 8. Monosyllabic patterns with long V-element, or with final- $\mathrm{CC}$ sequence

\begin{tabular}{|c|c|c|c|c|c|c|c|}
\hline Word & Structure & Word & Structure & Word & Structure & Word & Structure \\
\hline 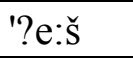 & CVVC & la? & $\mathrm{CVC}$ & & & & \\
\hline 'we:n & CVVC & & & ?a: & $\mathrm{CV}(\mathrm{V})$ & 'kunt & CVCC \\
\hline 'Su:S & CVVC & Tab & $\mathrm{CVC}$ & hai & CVV & 'šuft' & CVCC \\
\hline 'ki:f & CVVC & ma9 & $\mathrm{CVC}$ & 'fi: & $\mathrm{CV}(\mathrm{V})$ & 'rudd & CVCC \\
\hline 'ho:n & CVVC & miš & $\mathrm{CVC}$ & 'šai & CVV & & \\
\hline 'bo:t & CVVC & bas & $\mathrm{CVC}$ & ?a: & $\mathrm{CVV}$ & & \\
\hline 'Ge:r & CVVC & & & & & & \\
\hline ?a:1 & CVVC & & & & & & \\
\hline 'mi:n & CVVC & & & & & & \\
\hline 'fo:? & CVVC & & & & & & \\
\hline 'he:k & CVVC & & & & & & \\
\hline 'zGi:r & CCVVC & & & & & & \\
\hline 'Ga:d & CVVC & & & & & & \\
\hline ?u:m & CVVC & & & & & & \\
\hline 'Su:S & CVVC & & & & & & \\
\hline 'ho:n & CVVC & & & & & & \\
\hline 'le:š & CVVC & & & & & & \\
\hline
\end{tabular}


\begin{tabular}{|l|l|}
\hline 'zla:m & CCVVC \\
\hline
\end{tabular}

\section{Conversational Exchange (3): Accentual Patterns}

\subsection{Accentual Pattern (1)}

(i) Disyllabic words with final Long (heavy) syllables: CVVC, CVCC, CVV; stress falls on the ultimate syllable:

Table 9. Disyllabic words with final long, heavy syllables

\begin{tabular}{|l|l|l|}
\hline Word & Word & Word \\
\hline (CV-CVVC) & (CVC-CVVC) & (CV-CVCC) \\
\hline ?a'ki:d 'sure' & taq'di:r'appreciation' & ba9'rafś " I know' \\
\hline ka'ma:n more' & Tab'xi:n 'we cook' & bal'lašt ' I started' \\
\hline Ta'ba:t 'balls' & saw'we:t 'I did' & ?af'Tart' I had breakfast' \\
\hline Ha'ke:t I spoke' & xar'ba:n 'out of order' & \\
\hline Sa'r:9 'street' & za9'la:n 'cross' & \\
\hline Ba'Ti:? 'slow' & ta9'ba:n 'tired' & \\
\hline qi'Ta:r 'train' & Sal'Ha:n 'in good order' & \\
\hline 9a'ša:n' in order to' & & \\
\hline 'xalaaS 'enough' & & \\
\hline
\end{tabular}

\subsection{Accentual Pattern (2)}

(i) Patterns in which the penult is intermediate (i.e. CV, CVC) or Long (i.e.CVVC,CVV), stress falls on the penultimate:

Table 10. Patterns in which the penult is intermediate or long

\begin{tabular}{|l|l|l|l|l|l|}
\hline Word & Word & Word & Word & Word & Word \\
\hline CVV-CV & CVV-CVC & CVC-CV & CV-CV & CVC-CVC & CV-CVC \\
\hline $\begin{array}{l}\text { 'xa:lu } \\
\text { uncle' }\end{array}$ & 'xa:lid & '?ilha'hers' & '?ana & 'bakzib"lie' & 'walad' boy' \\
\hline 'sa:9a 'watch' & 'ta:9it 'hers' & & $\begin{array}{l}\text { darsak 'your } \\
\text { lesson' }\end{array}$ & \\
\hline 'te:ta 'granny' & '3a:mi9'mosque' & $\begin{array}{l}\text { 'minha from } \\
\text { her' }\end{array}$ & & & \\
\hline
\end{tabular}

(ii) Trisyllabic words with final Long syllables CVVC, CVCC, CVV; stress falls on the ultimate Long syllable:

Table 11. Trisyllabic words with final long syllables CVVC, CVCC, CVV

\begin{tabular}{|l|l|}
\hline Word & Word \\
\hline xara'bi: š 'scribbles & CV-CV-CVVC \\
\hline 9ala'ša:n 'in order to' & CV-CV-CVVC \\
\hline
\end{tabular}


(iii) Trisyllabic patterns in which the final syllable is Short (CV or CVC), the penult is not short receives stress on the penultimate:

Table 12. Trisyllabic patterns in which the final syllable is short (CVor CVC)

\begin{tabular}{|l|l|l|l|l|l|}
\hline Word & Word & Word & Word & Word & Word \\
\hline CVV-CV & CVV-CVC & CVC-CV & CV-CV & CVC-CVC & CV-CVC \\
\hline $\begin{array}{l}\text { 'xa:lu } \\
\text { uncle' }\end{array}$ & 'xa:lid & '?ilha'hers' & '?ana & 'bakzib"lie' & 'walad' boy' \\
\hline 'sa:9a 'watch' & 'ta:9it 'hers' & & $\begin{array}{l}\text { darsak 'your } \\
\text { lesson' }\end{array}$ & \\
\hline 'te:ta 'granny' & '3a:mi9'mosque' & $\begin{array}{l}\text { 'minha from } \\
\text { her' }\end{array}$ & & & \\
\hline
\end{tabular}

\subsection{Accentual Pattern 3}

Disyllabic words with intermediate or(not short) penult are stressed on the penult:

Table 13. Disyllabic patterns with intermediate or not short penult.

\begin{tabular}{|l|l|l|l|}
\hline Word & Structure & Word & Structure \\
\hline 'Tab9an 'of course & CVC-CVC & 'ba:Ina 'our thought' & CVCCV \\
\hline fikra 'idea' & CVCCV & ?ursum 'draw' & CVC-CVC \\
\hline 'Tayyib'O.K.' & CVC-CVC & 'ya9ni'that is' & CVCCV \\
\hline 'rakkiz ;focus' & CVC-CVC & ?iHna 'we' & CVCCV \\
\hline 'buxTur 'it occurs' & CVC-CVC & & \\
\hline 'ni9mal 'we do' & CVC-CVC & & \\
\hline
\end{tabular}

\section{Stress Placement Rules}

The analysis of the conversational exchanges in terms of their constituent syllables reveals the following facts about stress placement:

1) Patterns with final $-\mathrm{CVV}, \mathrm{CVVC}, \mathrm{CVCC}$ are stressed on the ultimate syllable, e.g. ba9'de:n ' (CV-CVVC) 'later on', $m a z ' b u: T$ (CVC-CVVC) 'correct',

baT'Talt (CV-CVCC) 'I gave up', Daw'wi: (CVC-CVV) 'switch it on',

Darabu: (CV-CV-CVV) 'they hit him', ka'kau (CV-CVV) 'cocoe'

2) Patterns with final CV or CVC i.e. 'intermediate' syllable -type or with CVVC penult are accented on the penultimate ,e.g. 'buzbuT (CVC-CVC) 'It'll be all right' 'hassa (CVC-CV) 'now', 'la:zim (CVV-CVC)' we have to', 'sa:9a (CVV-CV) ' a watch'

3) Trisyllabic patterns with sequences of three successive short syllables are accented on the antepenultimate,e.g. '9ašara CV-CV-CV 'ten', madrase (CVC-CV-CV) 'school'.

4) Trisyllabic patterns in which the ultimate syllable is short and the penult is Long are stressed on the penultimate, e.g. ma'sa:?il (CV-CVV-CVC) 'questions', ra'sa:?il 'messages'. 


\section{Macrothink}

5) Monosyllabic words with long vowel nucleus are made prominent, e.g.

'ho:n (CVVC) 'here', 'le:š (CVVC), 'ki:f (CVVC) 'how'

6) The most unmarked syllable -type is the final heavy CVV, CVVC, CVCC

e.g.?a9'Te:t ?iy'ya:h 'I gave it to him', lu'zu:m 'need', za'ma:n 'time'

\subsection{Stress Placement Constraints}

Stress placement constraints may be stated as the following:

\subsubsection{Monosyllabic Words}

The majority of this class of words is 'grammatical' and may be divided into two subsets: (i) Long monosyllabic words of the type CVV, CVVC or CVCC, and (ii) Short monosyllabic words of the type $\mathrm{CV}, \mathrm{CVC}$. The constraint is:

(i) Short monosyllabic words are never stressed; if they do, they are only stressed in response utterances; the short vowel becomes fully long, cf.

šu ma:lak? What"s the matter with you? vs. šu: ma:li 'What's the matter with me?, only uttered in response.

(ii) Front half open/open low vowels are not allowed in "emphatic' consonantal framework. Possible combinations of long and short vowels + coronal consonant or sonorant are cited below.

\subsubsection{Disyllabic Words}

Disyllabic words are higher in frequency in conversational exchanges than trisyllabic words. Apart from stressing consistently the ultimate syllable of structure CVVC, CVV, CVCC, stress placement is regularly placed on the penult Long syllable, e.g. 'sa:lim . The constraint is: final CV or CVC syllables are not accented. However; the principle of extrametricality which supports the view that "there is always some extra metrical materail at the right edge of the word and that "Word final C's are extrametrica" Ussishkin (2000:219) may not apply in all cases of disyllabic stress placement. Consider the following disyllabic words in which the final segments do not allow further extrametrical material: $k a$ 'man 'more', halla? 'now', la:zim 'have to 'ya9ni 'I mean', 'buzbuT 'would be all right', 'te:ta 'grandma', ka'kau 'cocoe'.

\subsubsection{Trisyllabic Words}

Where trisyllabic words contain no heavy syllables, stress falls by default on the first syllable. But otherwise stress falls on the right-most heavy syllable, cf:

Table 14. Trisyllabic with three short syllables, heavy penult and heavy syllable

\begin{tabular}{|c|l|l|}
\hline $\begin{array}{c}\text { Trisyllabic with 3 short } \\
\text { CV(C)-CV-CV }\end{array}$ & $\begin{array}{l}\text { Trisyllabic with } \\
\text { Heavy(long) Penult }\end{array}$ & $\begin{array}{l}\text { Trisyllabic with Final } \\
\text { Heavy Syllable }\end{array}$ \\
\hline '?ar-ba-9a'four' & $? i H-' k i:-l i$ & maw-d3u-'di:n \\
\hline 'mas-?a-leh 'question' & $\check{s} a H-H a:-T a$ & $? i s ̌-t a-' r e: t$ \\
\hline
\end{tabular}




\begin{tabular}{|l|l|l|}
\hline $\begin{array}{c}\text { 'xal-la-tak } \\
\text { 'allowed' }\end{array}$ & ma-'Sa:-ri & ?a-Daw-'wi: \\
\hline $\begin{array}{c}\text { 'mak-ta-beh } \\
\text { 'library' }\end{array}$ & ?iy-ya:-hum & da-na-'ni:r \\
\hline $\begin{array}{c}\text { 'mad-ra-she } \\
\text { 'school' }\end{array}$ & ta-'la:-te & ka-ra'te: \\
\hline 'maz-ra-9a'farm & ?a-'Ga:-ni & \\
\hline 'rat-ta-bat 'arranged' & tam'hi:-di & \\
\hline & kum-bju:-ter & \\
\hline & la-'Ha:-li & \\
\hline
\end{tabular}

\subsection{Syllable Sequences}

In English, but not in Arabic the onset of a mono-syllable may be a vowel/diphthong, e.g. 'odd', 'arm', 'eat', 'owl', 'oven', 'act', 'aunt', 'oh' ,' own', etc Also English permits sequences of two or more consonants in syllable -initial and syllable final positions ,e.g.'straw' , 'spray', 'splints', ' scrounged', 'strict', 'straw', 'twelfths'. Jordanian Arabic words permit up to two consonants initially with $\mathrm{C} 1$ consisting of a stop and $\mathrm{C} 2$ an approximant, e .g [bla:d] 'country' , [brau]'bravo', [mrai]'mirror' , [dru:s] 'lessons'. In final positions, they permit two-consonant cluster, e.g. [bard] 'cold', [ward] 'flowers', [d3ild], 'skin'. [9ind] 'near' [zla:m] 'men'.

In the corpus of the conversational exchanges examined, the following canonical syllable types recur:

Table 15. The recurrence of canonical syllable types.

\begin{tabular}{|c|c|c|}
\hline Type 1 : Short & $\begin{array}{l}\text { e.g.wa-la -?i-ši / 'nothing } \\
\text { at all' }\end{array}$ & $\mathrm{CV}-\mathrm{CV}-\mathrm{CV}-\mathrm{CV}$ \\
\hline Type 2: Intermediate & CVC, e.g. war-Ta & $\mathrm{CVC}-\mathrm{CV}$ \\
\hline Type 3: Long & CVVC, CVV, CVCC & \\
\hline
\end{tabular}

Most syllable types exhibit a three-tiered structure consisting of a syllable node 'ó' a $C V$-tier which dominates consonantal and vowel segments and a segmental tier consisting of bundles of features. The $\mathrm{V}$ element of the $\mathrm{CV}$ represents a syllable nucleus realized by one of the ten monophthongs ( i:, i, e:, a, a:, a:, a, o:, u, u:) or one of the two diphthongs(ai, au); a C element is not a peak and represents a syllable onset or coda. The syllable is the basic functional unit in the phonological system of Arabic which not only regulates the ways in which vowels and consonants combine but it is also the unit in terms of which constraints on syllable structure are best stated. Thus, in Arabic but not in English the sequence [tl] is allowed as an onset, but in English the sequence [tl] is only allowed so long as /t / and /1/ belong to different syllables; it is not allowed in the same syllable, cf:

Table 16. The sequence of [tl] in Arabic and English.

\begin{tabular}{|c|c|}
\hline $\mathbf{J A}$ & RP \\
\hline tla:9 'hills' & atlas \\
\hline
\end{tabular}


\begin{tabular}{l|l} 
tliff $\quad$ 'roll' & butler \\
\hline
\end{tabular}

Also, Arabic does not allow vowel onsets. English syllables beginning with a vowel are initiated by a 'glottal' stop when produced by Arab learners of English. The following Arabic combinations of sounds are allowed at adjacent syllable boundaries

\subsection{Prosodies of 'frontness' and 'backness'}

The syllable also plays an important role in controlling features whose domain extend over more than one segment in length, e. g. articulatory gestures characteristic of 'emphatic' articulation are not started and completed within a single segment but extends over the whole syllable or word. The dark 'emphatic' features spread all over the utterance, e.g./laTam/ 'slapped' beginning with 'dark' [1] followed by back open vowels and an 'emphatic' bilabial nasal. The darker 'emphatic' articulation of the neighboring sounds to / $\mathrm{T} /$ 'the denti-alveolar stop' is due to anticipatory co-articulation which works in both directions.

Prosodic features such as 'frontness'/'backness' or 'clearness'/'darkness' are characteristic of the whole syllable or word. For example, the vocalic melody pattern in /buZbuT/ is characterized by the feature of 'backness' whose domain is the whole word. The 'dark' or 'emphatic' features are not localized in the 'emphatic' consonants /Z/ and /T/ but their effect involves the initial bilabial consonant which is articulated with greater muscular tension. Morphologically, other related words are derived by modifying the consonantal root $-\mathbf{Z}-\mathbf{b}-\mathbf{T}$ internally and not simply by concatenation of affixes and roots. The resulting vocalic pattern ' frontness' vs. backness' assign the word to a particular derivational class (McCarthy: 1993 B) cf.:

\begin{tabular}{|c|c|c|c|c|c|c|}
\hline Root Tier & $\mathbf{Z}^{\mathbf{Z}}$ & b & & T & & (ZabaT) it's all right' \\
\hline Skeletal Tier & $\mathrm{C}$ & $\mathrm{C}$ & V & $\mathrm{C}$ & & \\
\hline Vocalic Mel. Tier & & & $\mathbf{a}$ & & & \\
\hline $\mathrm{R}$-Tier & $\stackrel{b}{b}$ & $\mathbf{Z}$ & & $\stackrel{\mathbf{b}}{\mid}$ & $T$ & (buZbuT) 'it'll be all right \\
\hline Sk-Tier & $\mathrm{C}$ & $\mathrm{C}$ & V & $\mathrm{C} \mathrm{V}$ & & \\
\hline V-Tier & & & $\mathrm{u}$ & $\mathrm{u}$ & & \\
\hline R-Tier & $\mathbf{m}$ & & & $\mathbf{Z b}$ & $T$ & (maZbu:T)'it's all right' \\
\hline Sk-Tier & $\mathrm{C}$ & $\begin{array}{l}\mathrm{V} \\
\mathrm{l}\end{array}$ & & CC $\mathrm{V}$ & C & \\
\hline V-Tier & & a & & $\mathrm{u}$ & & \\
\hline R-Tier & Z & $\underline{\mathbf{a}}$ & & i & $\mathbf{T}$ & (Za:biT) 'it's all right' \\
\hline Sk-Tier & C & & $\begin{array}{l}\mathbf{V} \\
\text { l }\end{array}$ & C & $\mathbf{V}$ & C \\
\hline V-Tier & & & $\mathbf{a}$ & & $\mathbf{i}$ & \\
\hline
\end{tabular}




\section{Mll Macrothink}

Features of 'emphasis' span the internal structure of all syllabic elements: the nucleus being realized as back open (low) /a /or / $\underline{\mathbf{a}}$ /, the onset which is realized phonetically by lateral expansion of the whole body of tongue during the articulation of $/ \mathbf{Z} /$ a dark denti-alveolar sulcal voiced fricative , /T/ a voiceless denti-alveolar 'emphatic' plosive and /m/ an 'emphatic' bilabial nasal. In contrast with 'backness', there are certain patterns, which are distinguished by vocalic melody of 'frontness', whereby the nucleus of the syllable is dominated by a front vowel:

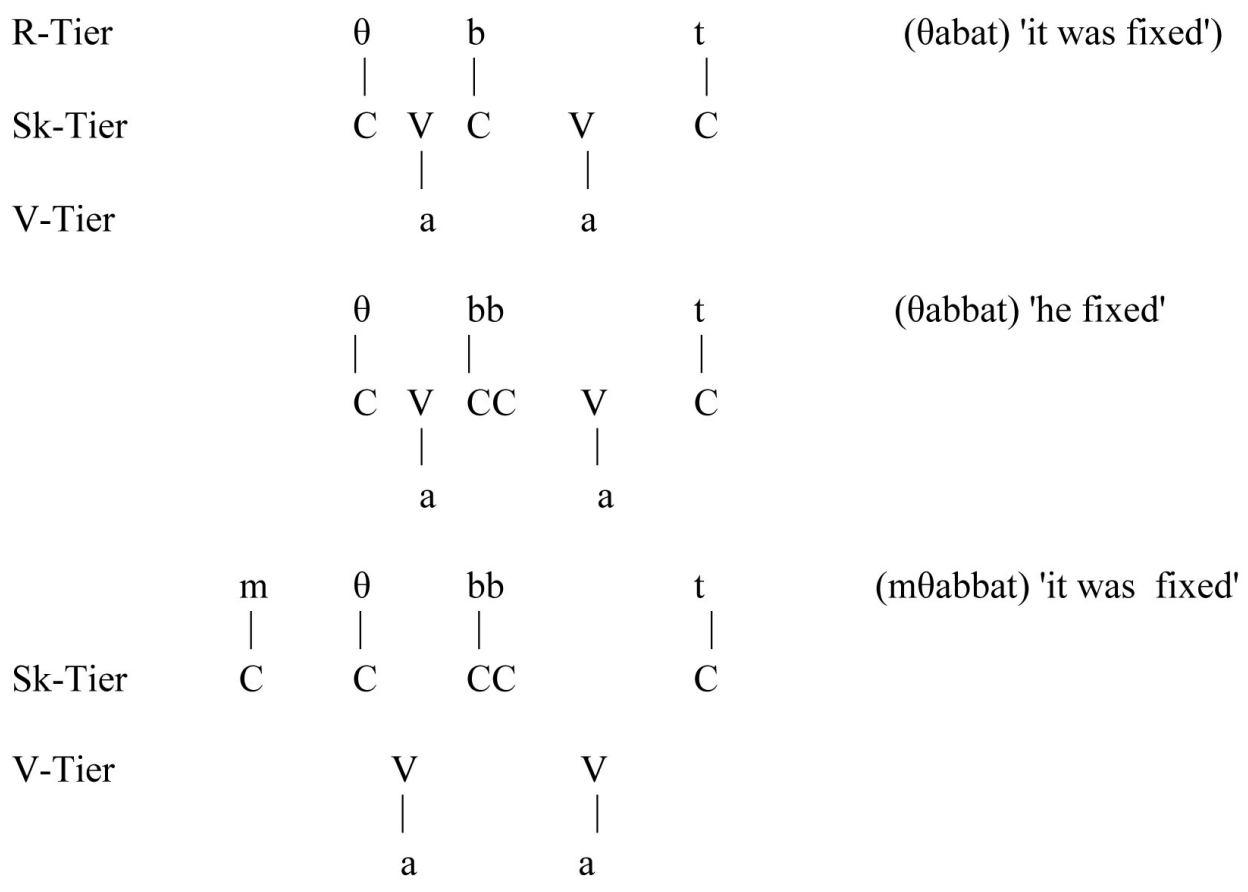

In the domain of 'clearness' or 'darkness', the constraints on consonant -vowel-consonant $(\mathrm{C}-\mathrm{V}-\mathrm{C})$ are known intuitively, based on the Arab learner's knowledge of the permissible syllable internal structure of the Arabic language. The Arab learner of English tends to transfer features of the whole prosodic template of the Arabic 'bunyaan' during the production of English utterances. Once these patterns are acquired, they become as independent lexical items that have their specific prosodic features and their own entry in an Arab learner's mental dictionary. Consider the following sample morphological patterns:

(i) $\operatorname{Infix}(\mathrm{es})$ :

Table 17. Infixes

\begin{tabular}{|l|l|l|l|l|}
\hline Infix(es) & $\begin{array}{l}\text { Input Base } \\
\text { (Root) }\end{array}$ & Output & Word -class & Semantic Info \\
\hline a-a & T-b-x & Tabax & verb & 'he cooked' \\
\hline a-a:-b & T-b-x & Tabba: $x$ & noun & $\begin{array}{l}\text { 'a person who } \\
\text { cooks' }\end{array}$ \\
\hline a-u: & T-b-x & maTbu: $x$ & verbal noun & 'being cooked' \\
\hline a-a & T-b-x & Tabxa & noun & 'the meal' \\
\hline a-i: & T-b-x & Tabi: $x$ & noun & 'cooking' \\
\hline
\end{tabular}


(ii) $\operatorname{Suffix}(e s)$ :

Table 18. Suffixes.

\begin{tabular}{|l|l|l|l|l|}
\hline -a:t & T-b-x & Tabxa:t & noun/fem.pl. & 'recipes' \\
\hline -i:n & T-b-x & Tabbaxi:n & noun/masc.pl. & 'cooks' \\
\hline
\end{tabular}

(iii) Prefixes:

Table 19. Prefixes.

\begin{tabular}{|l|l|l|l|l|}
\hline$-\mathrm{m}$ & T-b-x & maTbax & noun & 'kitchen' \\
\hline$-\mathrm{m}+\mathrm{a}:$ & T-b-x & maTa:bix & noun/pl. & 'kitchens' \\
\hline
\end{tabular}

(iiii) All:

Table 20. Infixes, suffixes, and prefixes.

\begin{tabular}{|l|l|l|l|l|}
\hline Infixes & $\begin{array}{l}\text { Input Base } \\
\text { (root) }\end{array}$ & Output & word-class & Semantic Info \\
\hline a-a & H-s-d & Hasad & noun & 'envy' \\
\hline a-u: & H-s-d & Hasu:d & noun & 'one who envies' \\
\hline a-s-a: & H-s-d & $\begin{array}{l}\text { Hassa:d } \\
\text { occupational }\end{array}$ & noun & 'one who envies' \\
\hline Suffix/es) & & & & \\
\hline i:n & H-s-d & Hassadi:n & noun(pl.asc.) & 'those who envy' \\
\hline a:t & H-s-d & Hassada:t & noun (pl.fem.) & \\
\hline Prefixes & & & & \\
\hline bj & H-s-d & bjiHsid & verb (imperfect) & 'he envies' \\
\hline
\end{tabular}

Table 21. Infixes, suffixes, and prefixes.

\begin{tabular}{|c|c|c|c|c|}
\hline infixes & $\begin{array}{l}\text { Input } \\
\text { Base(root) }\end{array}$ & Output & word class & Semantic info \\
\hline $\mathbf{a}-\mathbf{a}$ & H-S-d & HaSad & verb(imperfect) & 'he reaped' \\
\hline $\mathrm{a}-\mathrm{S}-\mathrm{a}: \mathrm{d}$ & $\mathrm{H}-\mathrm{S}-\mathrm{d}$ & HaSSa:d & noun & 'one who reaps' \\
\hline $\mathrm{a}-\mathrm{i}:$ & H-S-d & $\mathrm{HaSi}: \mathrm{d}(\mathrm{e})$ & noun & 'harvest' \\
\hline \multicolumn{5}{|l|}{ Suffixes } \\
\hline i:n/-a:t & H-S-D & HaSSSadi:n & noun.masc.pl/fem & \\
\hline \multicolumn{5}{|l|}{ Prefixes } \\
\hline $\mathrm{Bj}-$ & H-S-d & bjuHSud & verb & 'he reaps' \\
\hline at & H-S-d & Ha Sa aat & Verb (imp.) & 'she reapt' \\
\hline $\mathrm{u}$ & H-S-d & Ha $\underline{\text { Sadu }}$ & verb (imp./pl) & 'they reaped"' \\
\hline
\end{tabular}

Morphologically, the lexical meaning of the dictionary entry form 'lexeme' is signaled by the association of the triconsonantal root $\mathrm{H}-\mathrm{s}-\mathrm{d}$ vs. H-S-d at the root tier. Depending on the affixes and vocalic elements introduced, different word-forms realize different grammatical words. The skeletal tier, which is also called the prosodic template tier, not only regulates 
the association of consonant -vowel-consonant but also provides crucial information about the grammatical function of the canonical shape formed by such associations. Clearly, the association of the 'non-emphatic' voiceless fricative $/ \mathrm{s} /$ with the voiced 'non-emphatic'fricative /s/ and the restrictions imposed by the non-occurrence of a back open vowel as opposed to its occurrence in /HaSad/ is characteristic of the imperfect tense in Arabic. The V slot in the CVCVC is phonologically determined in the sense that the quality of the vowel is subject to restrictions imposed by anticipatory consonantal gestures of the 'non-emphatic'/s/ or its 'emphatic' counterpart/S/. The vocalic melody is 'frontness' for the 'non-emphatic'CVCVC template and the melody is 'backness' for the 'emphatic' CVCCVC template.

The Arab learner compares the linguistic features in L2 input with his own mental

lexico-grammatical templates, registering to what extent he could reduce the 'gap' between the input and his own mental templates applying L1 rules of syllabification and morphological concatenation. At a later stage he integrates a representation of the new L2 linguistic pattern into his interlanguage. Consider, for example, the contrast between the front /a/ vocalic melody vs. the back/a/ vocalic melody which Arabic reduplicative exhibit:

Table 22. The contrast between the front/a/ vocalic melody vs. the black / a/ vocalic melody

\begin{tabular}{|c|c|}
\hline Front /a/ vocalic melody & 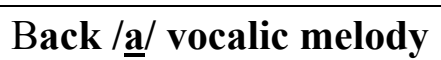 \\
\hline damdam & DamDam \\
\hline dabdab & $D \underline{a} b D \underline{a} b$ \\
\hline taftaf & TafTa $\bar{a}$ \\
\hline taltal & $T \underline{a} T \underline{a} l$ \\
\hline tamtam & TamTam \\
\hline samsam & SamSam \\
\hline 9ad9ad & $9 \underline{a} D 9 \underline{a} D$ \\
\hline 9as9as & $9 a S 9 a S$ \\
\hline wašwaš & $r \underline{a} \underline{s} r a \underline{s}$ \\
\hline balbal & barbar \\
\hline wakwal & warwar \\
\hline basbas & $b a S b \underline{a} S$ \\
\hline fasfas & $f \underline{a} S f \underline{a} S$ \\
\hline ta?ta? & Ta? Ta $\underline{?}$ \\
\hline salsal & SalSal \\
\hline laflaf & rafraf \\
\hline falfal & farfar \\
\hline
\end{tabular}

The skeletal tier template for reduplicative forms is CVCCVC in which the second syllable is a copy of the first; the vocalic melody is the front open centralized [a] in the environment of 'clear' consonants whereas the vocalic melody is open back / $a$ / in the environment of 'dark' consonants. A key point to note is the multiple linking of [a] or [a] with both V slots on the skeletal tier. 


\section{Macrothink \\ International Journal of English Language Education \\ ISSN 2325-0887 \\ 2013, Vol. 1, No. 1}

\section{Prosodies of 'clearness and darkness'}

Given the hypothesis of coarticulation, velarization and /or rhotazation is an articulatory process of two environments: the 'emphatic' or 'darkness' and the 'non-emphatic' or 'clearness'. The first process involves two gestures: tongue body retraction in anticipation of an upcoming 'emphatic' consonant and (ii) greater muscular tension in the articulating organs. Anticipatory lingual articulation involves the positioning of the tongue in 'emphatic'/'non-emphatic' articulation as a function of a preceding or following 'emphatic' consonant. The exponents of the prosody of 'clearness' are 'frontness': the front of the tongue is raised towards the hard palate; contact is made by the tip and blade of the tongue against both the dental and the alveolar zones of the palate. The whole body of tongue is laterally contracted in relation to the roof of the mouth. On the other hand, an 'emphatic' articulation gives rise to a reduction of the pharyngeal space as a result of flattening the tongue. Gestures are organized in co-coordinative structures. In CVCV, CVCCVC sequences constraints imposed by 'emphatic' consonants appear to control the tongue dorsum. Anticipation of an upcoming 'emphatic' consonant will alter articulation. That tongue retraction results in lowering formant values particularly those of F2 is evidenced by $\mathrm{S} 1$ higher formant values in sequences characterized by the prosody of 'clearness'.

The arrangement of syllables in the phonological organization of Arabic has a considerable effect on the Arab learner's ability to organize L2 syllables. In his early stages of learning English, he tends to reorganize L2 syllables and adapt them so that they conform to L1 syllabic structure. Consider, for example, the arrangement of the syllabic structure of the following conversation between two female Jordanian friends:

wen 't o:k-ing a 'baut 'taim, w: 'to:k a-'bout wat 'bi:-bul du: wï ðe:r

Taim wi: ðеn ju:z ðə ve:rbz spent, pa:s and we:st. tu spend ðə Taim ?iz tu 'du: Sam Өing ju:z-ful wið ju:r Taim....wi: 'spend ðə 'de: kli:ning ðə 'haus

jes 'ju: 'du;, ju: du: bat ai 'don't, ai 'don't.

we:r ?iz ju:r mag.

- ai don’t no: we:r it ?iz,?it iz ?in ðə sink .?it needz tu bi: 'wo:šd. ðe:r ?it ?iz.

- $\quad$ wat du: ju: aink ov ?it?

- $\quad$ ?t ?iz va-ri gud. we:r did ju bai ?it.

- $\quad$ it wa:z a prezint from a frend hu: went ?on ?e: tu:r to ?is-ba:n-ja la:st ji:r.

- $\quad$ ki:p ?it ?a:z a su:-vi-ni:r.

- hau ?a:r ju: go:-ing tu spend ju:r taim tu-de:?

- $\quad$ I want tu kuk.

- $\quad$ wat ?a:r ju: kuk-ing?

- $\quad$ mansaf. ?o:1 ?ov ðem lav ?it. 
- bai ðe we:, hau wa:z ð ə pa:r-ti?

- ju: mi:n ð ə tšil-drin'z pa:r-ti?

- jes.

- hau long did ?it te:k?

- $\quad$ wan ?au-er ?and fo:r-t mi-nits.

- Wat did ju: we:r fo: ðə pa:r-ti?

- $\quad$ e: gre: su:t.

- $\quad$ 0is ?iz nju: , ?on mai be:ra-de:, ?e: prezent

Constraints on Arabic syllable structure are operative in the text above. They serve as a filter allowing only a limited number of vowels specific to Arabic to occur. English words are reconstructed so that only sound sequencesmodeled on the Arabic prosodic templates to occur. How deeply ingrained syllable structure rules in the minds of Arab learners can be evidenced from the conversational exchange cited above, cf.

Table 23. The arrangement of syllabic structure in Arabic and English

\begin{tabular}{|l|l|l|}
\hline JA & Syllable Structure & \multicolumn{1}{|c|}{ RP } \\
\hline$d o n t$ & CVCC & VVC 'don't don't['dəunt] \\
\hline$j u: r$ & CVVC & CVV' your your [jäa] \\
\hline suvi'ni:r & CV-CV-CVVC & $\begin{array}{l}\text { CVCVCVV souvenir [su } \\
\text { və'niə] }\end{array}$ \\
\hline we:r & CVVC & \\
\hline
\end{tabular}

Stress placement in Arabic is sensitive to the internal structure of the syllable that bears it. A balanced proportion of light, intermediate or heavy syllables is maintained throughout oral discourse. When producing English utterances, Arab learners tend to maintain this balance. Consequently; vowels in the English unstressed syllables have clear or full vowel quality. English polysyllabic words are restructured so that the constituent syllables follow typical Arabic syllabification. Consider the following utterances extracted form the conversational exchange cited above, wherein the English 'muffled' vowel quality like that of schwa is realized as a 'pure full' vowel:

Table 24. Stress placement in Arabic and English

\begin{tabular}{|l|l|}
\hline \multicolumn{1}{|c|}{ JA } & RP \\
\hline /don't/ CVCC & \multicolumn{1}{c|}{ 'can, /[kən/] } \\
\hline /ji:r/ CVVC & /'don' [dəunt/ ]' \\
\hline
\end{tabular}

When considering stress placement in both languages, an algorithm which constructs two sets of prosodic templates in both languages is essential. The first set is assumed to highlight similarities of stress placement and the other will deal with differences. The pedagogical 
implication is to facilitate and speed up the learning process. In both languages, one has to take into account the fact that stress is a relational concept: a stressed $\backslash$ syllable is more salient than its adjacent unstressed counterparts. Stressed syllables are longer, louder and higher in pitch. The location of stress is determined by the internal structure of the word. In particular, the syllable weight plays an important role in stress placement. In both languages, all lexical words must have one syllable, which receives primary stress. Clearly; monosyllabic words which contain a long vowel like English boy, toy, aunt, farm and Arabic/ he:k, hai , ho:n, le:š/ are stressed.

The location of stress in disyllabic words in both languages is quantity sensitive. Where disyllabic verbs contain no heavy syllables, stress falls by default on the first syllable, cf.

Table 25. Disyllabic verbs in both languages contain no heavy syllables.

\begin{tabular}{|c|c|}
\hline $\mathbf{J A}$ & $\mathbf{R P}$ \\
\hline 'Haki & 'carry [kæri] \\
\hline 'sawwi & 'copy [kapi] \\
\hline 'ruHtu & 'cover [kavə] \\
\hline 'ya9ni' & 'singer' [sinə] \\
\hline 'maši & 'walking [wa:kin] \\
\hline
\end{tabular}

If, on the other hand, the syllable is heavy i.e contains a long vowel or diphthong stress falls on that syllable, $\mathrm{Cf}$.

Table 26. Disyllabic verbs contain heavy syllables.

\begin{tabular}{|l|l|}
\hline JA & RP \\
\hline sa'ri:9-'ki:d & glori'fy \\
\hline ba'Ti:? & re'ceive [risiv] \\
\hline Qi'a:r & re-'cur [ri'kӘ:] \\
\hline ?a'na:m & red'uce \\
\hline 9an'3add & con'coct[ \\
\hline ma'ri:D & enlist \\
\hline ra:'me:t & pre'fer [prifӘ:] \\
\hline za9'la:n & av'oid [Ә vp:d] \\
\hline ba9'de:n & re'fine \\
\hline la'we:n & co'coon \\
\hline
\end{tabular}

In passing, however, one has to account for exceptional cases. Some words in both languages are stressed on the first syllable although the final syllable contains a long vowel or diphthong, e.g. follow, yellow, (Arabic /'yad3ri(:)/, 'run').

Turning now to trisyllabic words, we find the similarities in the location of stress outweigh differences. Ignoring the final syllable which is extrametrical, we find that in both languages stress lands on the penultimate syllable if it is heavy, $\mathrm{Cf}$. 


\section{Mll Macrothink}

Table 27. Trisyllabic words in both languages where stress lands on the penultimate syllable if it is heavy.

\begin{tabular}{|l|l|}
\hline JA & RP \\
\hline ma'sa:kin 'houses' & tor'nado \\
\hline ma'd3alis 'councils' & bron-'chi-tis \\
\hline tam'hi:di 'elementary' & ban'nanas \\
\hline fard3a:ni 'he showed me' & to'matoes \\
\hline la'Ha:li 'alone' & po'tatoes \\
\hline
\end{tabular}

If, on the other hand, the penultimate syllable is light, stress falls on the ante-penultimate syllable, cf.

Table 28. Trisyllabic words in both languages where the penultimate syllable is light.

\begin{tabular}{|l|l|}
\hline JA & \multicolumn{1}{|c|}{ RP } \\
\hline 'marHaba & 'ci-ne-ma \\
\hline 'muškila & 'positive \\
\hline 'mas?ala & 'Saterday \\
\hline 'taðkara & 'hospital \\
\hline '?alamak & 'furinture \\
\hline 'madrasa & 'generous \\
\hline fugara & 'visitor \\
\hline
\end{tabular}

\section{The Effect of Adjacent Consonants on V-V}

\subsection{The Effect of the Preceding or Following Consonant}

From the analysis of the L1 and L2 conversational exchanges, we find that the prosodic features of the Arabic morphological patterns have a considerable effect on L2 Arabic pronunciation. To facilitate the task of L2 pronunciation, English sounds are modified to make them similar to L1 sounds. The process is bidirectional: a sound becomes 'clear' or 'dark' according to whether the sound that precedes is 'clear or 'dark', or whether it is influenced by the sound that follows it. Here are some of the commonest coarticulatory processes found in L2: Arab learners of English are still learning English with spoken input that is modeled on spoken Arabic sound patterns.

\subsection{The Effect of L1 Prosodic Template}

Words may be perceived by L2 learners as much in terms of their orthographic shape as their phonological shape, whereby the learner makes a mental image that connects L2 words with L1 words that have some formal sound association with typical Arabic word templates. For example, if the target word is' photograph', the learner is highly likely to associate that with prosodic templates of, say, maHallaat ' 'shop'/maTabba:t/' bumps' ,etc, in which the ultimate ,not the antepenultimate syllable, is stressed and during the production of which the Arabic canonical vowels are realized, viz /'futugra:fs/ instead of. The general shape of the incoming word is crucial. The learner recognizes the first or the last syllable and takes note of 
how many syllables it contains; the general constituent structure, where the stress falls in terms of L1 stress rules and what sort of vowels should be filled in the slots, so to speak. If the general shape of an L2 word has been matched with a stored Arabic template that is more or less equivalent to an L2 template, L2 output patterns are realized as L1 structural patterns, Cf.

Table 29. The effect of L1 prosodic template

\begin{tabular}{|c|c|}
\hline $\mathbf{R P}$ & $\mathbf{J A}$ \\
\hline re'mind & /ka'ma:n /'more' \\
\hline re'form & / jo'me:n/'a couple of days' \\
\hline re'tain & $\begin{array}{l}\text { /?ah'le:n, } \\
\text { /sahle:n/ ,welcome/ } \\
\text { ba9'de:n/'later' }\end{array}$ \\
\hline recall & $\begin{array}{c}\text { bi'du:n/' without', } \\
\text { /bi'Si:r/ 'possible }\end{array}$ \\
\hline reply & $\begin{array}{l}\text { /wa'rai/ 'behind me',/ } \\
\text { ma'9ai/ 'with me' }\end{array}$ \\
\hline
\end{tabular}

\subsection{The Effect of L1 Syllabic Structure}

Syllabic structure of most spoken Arabic words are mono, di-or trisyllabic. When faced with an unfamiliar polysyllabic word of more complex phonological structure, certain L2 sound sequences are deleted

\section{4 'Glottal' Stop Initiation}

While any English vowel can begin a word, Arabic vowels do not begin words. When vowels initiate an utterance, Arab students use a 'glottal' stop in each word beginning with a vowel.

\subsection{Phonatactic Restrictions}

The rules regulating the positions in which various sounds may occur in a word and the combinations of sounds that are permissible are different in L1 and L2. For instance, there are phonatactic restrictions on the combination of 'dark'/'clear' 1 in various positions in a word in spoken Arabic. The occurrence of Arabic 'clear' 1 is subject to restrictions imposed by the non-occurrence of 'emphatic' or 'dark' consonants in the immediate neighborhood of the sound. The occurrence of 'dark' 1, on the other hand is governed by the occurrence of another adjacent 'dark' or 'emphatic' consonant. The phonatactic restrictions which apply to English 1 sounds are different. English 'dark' 1 occurs in word-final or in pre-consonantal positions, e.g. smell, bull, cuddle, fulfill. The occurrence of 'dark' 1 is not conditioned by the presence of another adjacent 'dark' consonant as in Arabic. The articulatory gestures associated with English dark or valorized 1 in which the back of the tongue is simultaneously raised towards the soft palate as the blade of the tongue makes contact with the teeth-ridge (cf. Paula West, 1999) are not maintained by Arab L2 learners. English dark 1 is nearly always realized as 'clear' following the anticipatory co-occurrence of Arabic 'clear' 1 with 'non-dark' consonants. For example, 'dark' 1 is realized as clear in little, bottle, huddle, cuddle, milk, table, tilt, etc. 


\section{Results}

The results of this research are the following:

(i) The constraints on $\mathrm{C}-\mathrm{V}-\mathrm{C}$, in the domain of 'clearness'/'backness are known intuitively by the Arab learner of English. During the production of English utterances, the tendency is totransfer features characteristic of the Arabic prosodic templates.

(ii) In CVCV, CVCCVC constraints imposed by 'emphatic' consonants appear to control the tongue dorsum. Anticipation of an upcoming 'emphatic' consonant will alter the articulation; English words are reconstructed so that only sound sequences modeled on the Arabic prosodic templates are allowed to occur. English diphthongs are monophthongised and English 3-consonant clusters are reduced by the insertion of an anaptyctic vowel.

(iii) Words are perceived by Arab learners as much in terms of their orthographic shape as their phonological shape, whereby the learner makes a link between L2 words with L1 words that have similar sound associations with typical Arabic templates The phonatactic rules which apply to Arabic sounds are transferred to English.

(iv) The syllable is the hub of the Arabic phonological organization. It is the basic functional unit which not only regulates the ways in which vowels and consonants combine but it is also the unit in terms of which the effect of consonant on vowel can be determined or tested.

The syllable also plays an important role in controlling features whose domain extend over more than one segment in length, e. g. articulatory gestures characteristic of 'emphatic' articulation are not started and completed within a single segment but extends over the whole syllable or word. The dark 'emphatic' features spread all over the utterance, e.g./1 a $\mathbf{T}$ a $\mathbf{~ m} /$ 'slapped' beginning with 'dark' [1] followed by back open vowels and an 'emphatic' bilabial nasal. The darker 'emphatic' articulation of the neighboring sounds to / $\mathrm{T} /$ 'the denti-alveolar stop', is due to anticipatory co-articulation which works in both directions.

\section{References}

Allen, W. S. (1956). Structure and System in the Abaza Verbal Complex. Transactions of the Philological Society, pp. 127-176.

Barakat, Melissa and Francois Pellegrino. (1999). "Investigating Dialectal Differences Via Vowel System Modeling: Application to Arabic. San Francisco: ICPhS99, 145-148.

Firth, J. R. (1948). Sounds and Prosodies. Transactions of the Philological Society, 127-52.

Hockett, C. F. (1955). Manual of Phonology in International Journal of American Linguistics. Baltimore: Waverly Press.

Kent, Raymond, \& Fred Minifie. (1977). Co articulation in Recent Speech Production. J. of Phonetics, 5, 115-133.

Lado, R. (1957). Linguistics across Cultures. Ann Arbor: University of Michigan Press. 
Lehn, Walter, \& Slager. (1959). A contrastive Study of Egyptian Arabic and American English: The Segmental Phonemes. Language Learning. Volume 9, Issue 1-2, pages 25-33.

McCarthy, J., \& Prince. (1993a). Generalized Alignment. Technical Report\# 7 of the Rutgers Center for Cognitive Science, Rutgers, NJ.

McCarthy, J., \& Prince. (1993b) Prosodic Morphology. Tech Rep. \#3 of the Rutgers Center for Cognitive Science, Rutgers, NJ.

Mitchell, T. F. (1989) English Pronunciation for Arabic Speakers. Essex: Longman.

Mitchell, T. F. (-1961). Prominence and Syllabification in Arabic. BSOAS 23.269-89.

Robins, R. H. (1957). Aspects of Prosodic Analysis. Proceedings of the University of Durham Philosophical Society 1, series B (arts), pp. 1-12.

Stockwell, R. (1965). The Sounds of English and Spanish. Chicago: University of Chicago Press.

West, Paula (1999). The Extent of Co articulation of English Liquids an Acoustic and Articulatory Study" San Francisco: ICPh 99, 1901-1904.

Zeroual, Chaker. (1999) "A Fiberscopic and Acoustic Study of "Guttural" and Emphatic Consonants of Moroccan Arabic". San Francisco: ICPh99,997-1000.

\section{Notes}

The letters used in the transcription of recorded and the cited example have, in the main the phonetic values of the IPA symbols. However the following letters have been used throughout the text with the following phonetic labels:

/T/ voiceless 'emphatic' denti-alveolar plosive

/D/ voiced 'emphatic' denti-alveolar plosive

/ठ/ voiced dental fricative

/ / / voiced 'emphatic' dental fricative

/S/ voiceless 'emphatic' denti-alveolar fricative

/?/ glottal stop

/9/ voiced pharyngeal fricative

/H/ voiceless pharyngeal fricative

/G/ voiced velar fricative

$/ \mathrm{x} /$ voiceless velar fricative

/a/ an open front centralized vowel

/a/ back open vowel

/o:/ back mid rounded vowel 


\section{Macrothink

Appendix 1

Conversation Exchanges (1, 2, and 3)

CONVERSATIONAL EXCHANGE (1)

The following text is a transcript of a conversational exchange recorded between a 4 year old child and his 14 year old sister. In the syllabification process displayed under each utterance, consonants and vowels are indicated by the common $\mathrm{C}$ and V symbols; vowel length is indicated by VV and stressed syllables are shown by a little stroke place above the stressed syllable. The phonetic values given to consonant and vowel symbols are shown in Appendix ( ):

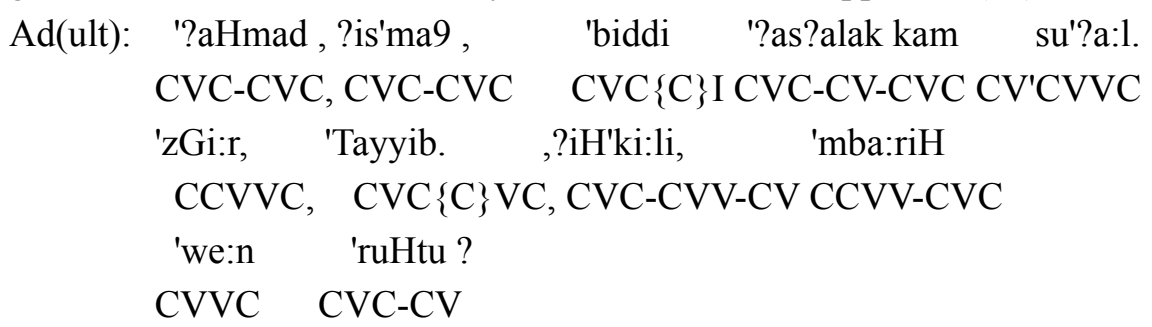


Ad.

?u 'humme

'?arba9a

$\mathrm{CV} \quad \mathrm{CVC}\{\mathrm{C}\} \mathrm{V} \quad \mathrm{CVC}-\mathrm{CV}-\mathrm{CV}$

?iH'k:li ka'ma:n im'ba:riH 'suft i'sta?

CVVC-CV CV-CVVC CCVVC-CVC CVCC CCV

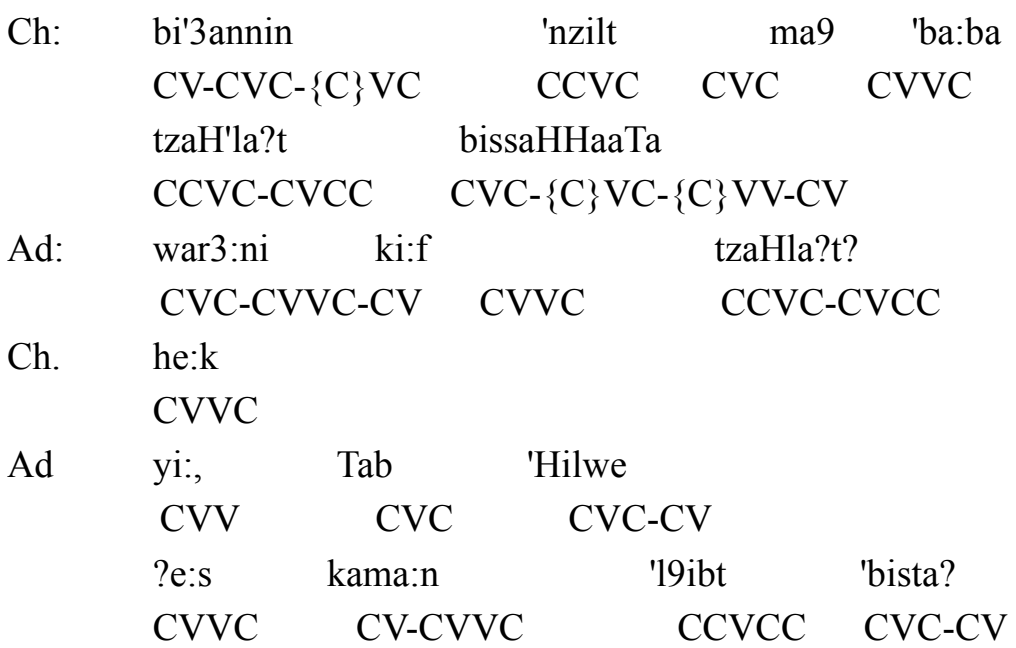

Ch. wala ?isi

$\mathrm{CV}-\mathrm{CV} \quad \mathrm{CVCV}$

Ad. Tab xallatak 'ma:ma 'tinzal

CVC CVC- $\{\mathrm{C}\}$ V-CVC CVVCV CVC-CVC

'9a:di ?

CVV-CV

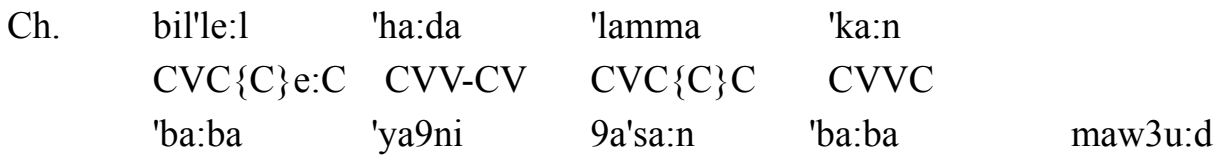

CVV-CVCVC-CVCV-CVVC CVV-CV CVC-CVVC

Ad. '9a:di, 'btiTla9

CVV-CV CCVC-CVC

$\mathrm{Ch} \quad \mathrm{mm}$

Ad ?ad'de:s 'ma9ak ma'Sa:ri? war'3i:ni

CVC-CVVC CV-CVCCV-CVV-CV CVC-CVV-CV

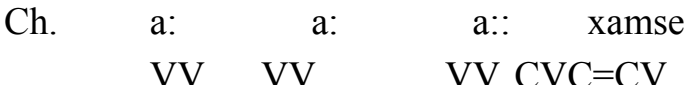

Ad. su: xamse ?adde:s

CVV CVC-CVCVC- $\{C\} V V C$

Ch. haa hal?add

CVV CVC-CVC $\{\mathrm{C}\}$

Ad. war3i:ni ?iyyaahum CVC-CVV-CV CVC $\{C\} V V C V C$

Ch. $\mathrm{mm} \quad \mathrm{mm} \quad \mathrm{mm}$

CC CC CC

Ad. ?e:s biddak tistri fi:hum 
CVVC CVCCVC CVC-CCV CVV-CVC

Ch. a: a: Talq

VV VV CVCC

Ad Talq?

Ch. $\mathrm{mm}$

$\mathrm{CC}$

Ad. btif?a9 ya9ni zay xa:lid

CCVC-CVC CVC-CVCVC CVV-CVC

$\mathrm{Ch}, \quad \mathrm{mm}$

$\mathrm{CC}$

Ad. Tayyib

CVC $\{C\} V C \quad C V-C V V-C V$

Ch. tala:te

CV-CVV-CV

Ad. talt Šlu:n

CVCC CCVVC

Tayyib ?e:s btiHDar 9ala sbe:s tu:n

CVC- $\{C\}$ VC CVVC CCVCCVC CV-CV CCVVC CVVC

Ch. ?e: ?abTa:1 ?iddi3ital

CVV CVC-CVVC CVC- $\{\mathrm{C}\} \mathrm{V}-\mathrm{CV}-\mathrm{CVC}$

Ad. mi:n bitHibb bi?abTa:l iddi3ital?

CVVC CVC-CVC $\{C\}$ CV-?CVC-CVVC CVC $\{C\} V-C V$

Ch. d3a:riH

CVV-CVC

Ad. d3a:riH? Tab Ti:r zayyu ?asu:f

CVV-CVC CVC CVC $\{C\} V \quad$ CVCCV CV-CVVC

Ch. he:k ?a: wibyiTlaq na:r

CVVC CVV CVC-CVC-CVC CVVC

Ad, ?e:s bitHibb ?inte filbe:t

CVVC CVCCVC $\{\mathrm{C}\}$ CVC-CV CVC-CVVC

Ch kura kura kura

$\mathrm{CV}-\mathrm{CV} \quad \mathrm{CV}-\mathrm{CV} \quad \mathrm{CV}-\mathrm{CV}$

Ad. kura? su lo: $\mathrm{n}$ kuratak?

CV-CV CV CVVC CV-CV-CVC

Ch Safra

CVCCV

min we:n ?istare:tha/

CVC-CVCVC CVVC CVC-CV-CVVC-CV

Ch. min 9indilmaktabeh

CVC CVCC vC-CVC-CV-CVC

Ad. bitHibb il?aGa:ni ?inte?

CVC-CVCC VC-CV-CVV-CV CVC-CV

$\mathrm{Ch} \quad \mathrm{mmm}$ 
$\mathrm{CC}$

Ad zay ?e:s?

CVC CVVC

Ch zay ?alla 9ale:k ya si:di.

CVC CVC- $\{\mathrm{C}\} \mathrm{V}$ CV-CVVC CV CVV-CV

Ad ?aw zay?

CVC CVC

Ch. ?aw sin kunti ?u bas

CVC CVC CVC-CV CV CVC

Ad Tab Ganni:li 'waHade

CVC CVC- $\{\mathrm{C}\} \mathrm{V}-\mathrm{CV} \quad \mathrm{CV}-\mathrm{CV}-\mathrm{CV}$

Ch halla?

$\operatorname{CVC}\{\mathrm{C}\} \mathrm{VC}$

Ad. we:n smi9t hai il?uGniye?

CVVC CCVCC CVV VC-CVC-CV-CV

Ch hai fi be:tna

CVV CV CVVC-CV

Ad mi:n biHuTha fi be:tkum?

CVVC CV-CVC-CV CVCVVC-CVC

Ch ?e:h ..... lamma....

CVVC $\quad \mathrm{CVC}\{\mathrm{C}\} \mathrm{V}$

Ad lamma btudrus

$\mathrm{CVC}\{\mathrm{C}\} \mathrm{V} \quad \mathrm{CCVC}-\mathrm{CVC}$

lamma tudrus bitHuT

$\mathrm{CVC}\{\mathrm{C}\} \mathrm{V} \quad \mathrm{CVC}-\mathrm{CVC} \quad \mathrm{CVC}-\mathrm{CVC}$

Ch. marra tistGil

CVC $\{C\} V \quad C V C C-C V C$

Ad.. lamma tku:n btistGil filbe:t

CVC $\{C\} V$ CCVVC CCVC-CCVC CVC-CVVC

btisbah ?e:s ?inta?

CCVC-CVC CVVC CVC-CV

Ch. $\mathrm{m} \mathrm{m} \mathrm{m}$

$\mathrm{C} \mathrm{C} \mathrm{C}$

Ad. zay mi:nbtisbah

CVC CVVC CCVC-CVC

Ch. lamma

$\mathrm{CVC}\{\mathrm{C}\} \mathrm{V}$

Ad. bitHibb itku:n btisbah lamma

CVC-CVCC CCVVC CCVC-CVC CVC $\{\mathrm{C}\{\mathrm{V}$

Ch. ?a:

CVV

Ad le:s?

CVVC 
le:s biddak tisbah lamma

CVVC CVC- $\{\mathrm{C}\}$ VC CVC-VCC CVC- $\{\mathrm{C}\} \mathrm{V}$

Ch he:k

CVVC

Ad. mi:n kama:n bimu:t ? mi:n suft

CVVC CV-CVVC CV-CVVC

Hada bimu:u?

CV-CV CV-CVVC

Ch. si:di ma:t

CVV-CVCVVC

Ch suftu lamma ma:t

CVC-CVCVC $\{C\}$ V CVVC

Ch. la?..... ya.. Hara:m min 9ind ilHiffe

CVC CV CV-CVVC CVC CVCC ve-CVC $\{\mathrm{C}\} \mathrm{V}$

biddu yiTla9 min ilHamma:m wi?i9

CVC $\{\mathrm{C}\} \mathrm{V}$ CVC-CVC CVC ev-CVC $\{\mathrm{C}\}$ VVC CV-CVC

d3alta hai

CVC-CVCVV

Ad d3alTa

Ch. ?a: d3alaTu: hum kulhum

CVV CV-CV-CVV CVC CVC-CVC

Ad. mi:n hum, mi:nhum?illi d3alaTu:?

CVVC CVC CVVC CVC CVC $\{\mathrm{C}\} \mathrm{V}$ CV-CV-CVV

ma: biddak tiHk:li mi:n hum?

CVV CVC $\{\mathrm{C}\} \mathrm{VC}$ CVC-CVV-CV CVVC CVC?

Ch. ?a: kulhum. 9amti

CVV CVC-CVC CVC-CV

hayfa kulhum xalaS ma: baHki

CVC-CVCVC-CVC CV-CVCCVV CVC-CV

Ad ?ahmad biddi ?awar3i:k Suwar.

CVC-CVC CVC $\{\mathrm{C}\} \mathrm{V} \quad \mathrm{CV}-\mathrm{CVC}-\mathrm{CVVC} \quad \mathrm{CV}-\mathrm{CVC}$

biddiyya:k tiHki:li su ?asma:?hum

CVC- $\{\mathrm{C}\} \mathrm{V}-\mathrm{CVVC} \quad$ CVC-CVV-CV CV CVC-CVVC-CVC

Ch. O.K.

CVV, CVV

Ad ?inte sa:Tir, Tab ta9a:1 ?asu:f

CVC CV-CVVC CV-CVVC

yalla, hai iSSura

CVC $\{C\} V \quad$ CVV CCVV-CV

Ch hai xya:r

Ad Tayyib ?u ?e:s hai kama:n? hai

CVC $\{C\}$ VC CV CVVC CVV CV-CVVC 
Ch ma: ba9rif

CVV

CVC-CVC

Ad ?u hai

$\mathrm{CV}$ CVV

Ch ma: ba9rif

CVV CVC-CVC

Ad. ?u hai?

Ch Hake:tlik

?iyya:ha

CV-CVVC-CVC CVC- $\{\mathrm{C}\} \mathrm{VV}-\mathrm{CV}$

Ad ?e:s hi:?

Ch 'filfil 'Hilu

CVC-CVC CV-CV

Ad. bti9raf ?iHna la?e:s binsawwi

CCVC-CVC CVC-CVCV-CVVC CVC-CVC $\{C\} V$

ilbando:ra wilixya:r wil3azar

ve-CVC-CVVC-CV CV-CVC-CVVC CVC-CV-CVC

bti9raf la?e:s binsawwi:hum?

CCVC-CVC CV-CVVC CVC-CVC $\{C\} V V-C V C$

$\mathrm{Ch}$

lazzift ?a: ?aSdi lal?akl

CVC- $\{C\} V C \quad C V V \quad C V C-C V C V C-C V C C$

we:n ?alami il?aswad?

CVVC CV-Cv-CV vc-CVC-CVC

Ad. ?alamak il?aswad ba9rafs

CV-CV-CVC ve-CVC-CVC CVC-CVCC

we:n la?e:to

CVVC CV-CVV-CV

Ch. 9aTTa:wle

CVC $\{C\}$ VVC-CV

Ch. mi:n ?illi biSalli?

CVVC CVC $\{C\} V \quad$ CV-CVC- $\{C\} V$

Ad ma:ma

CVV-CV

Ch mi:n kama:n?

CVVC CV-CVVC

Ad ba:ba

CVV-CV

Ch. mi:n?

CVVC

Ad $\quad$ xa:lid

CVV-CVC

Ch ?u ?abu xa:lid

CV CV-CV CVV-CVC

Ad mi:n ?abu xa:lid 


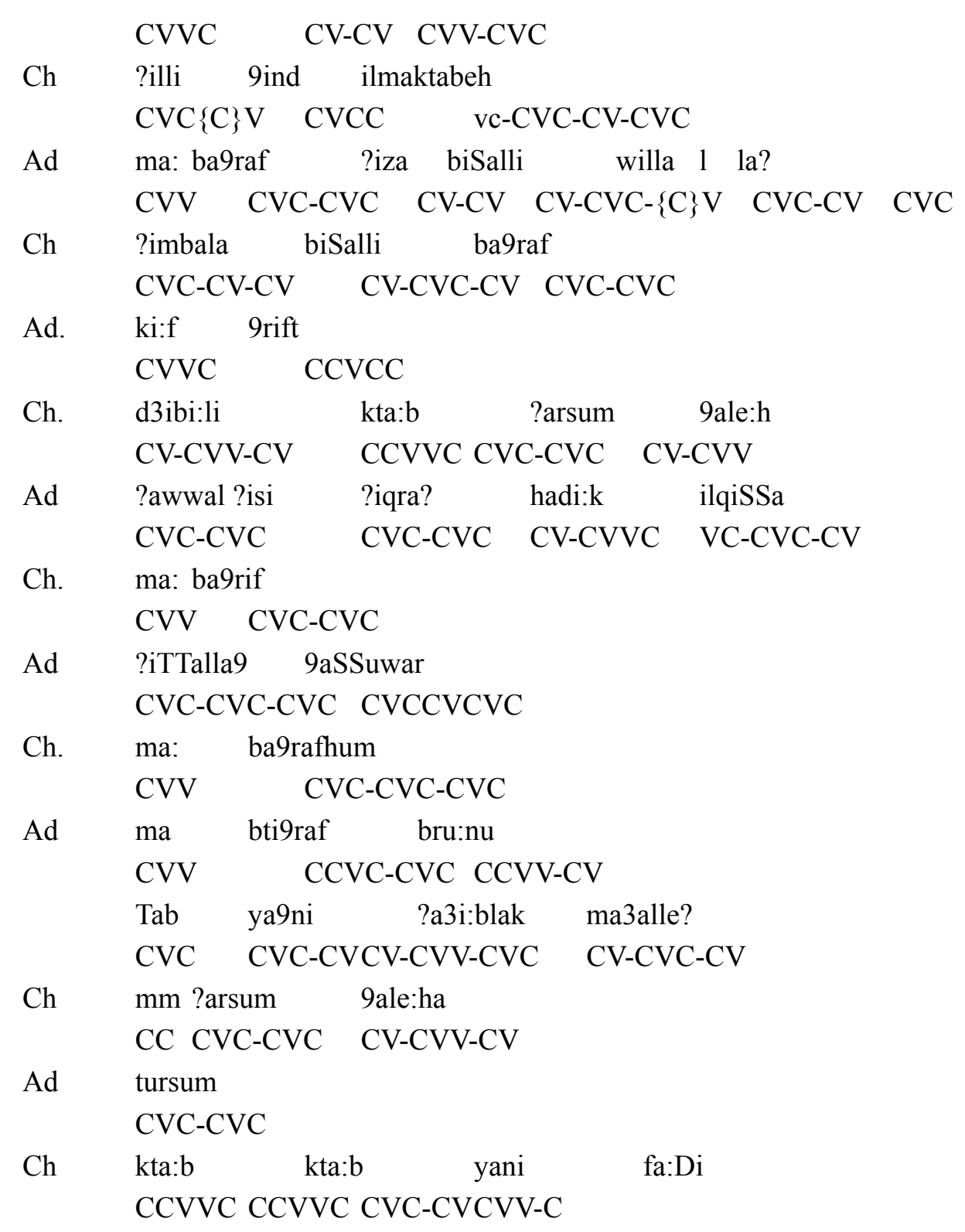

\section{Conversational Exchange (2)}

This is an exchange between Mohammad, a four year-old boy and his parents. The corpus consists of spontaneous utterances recorded over a period of four weeks. All participants in the exchange are native speakers of Jordanian Arabic. The transcription contains instances of substitutions (i.e. replacement of normal sounds, which the child is unable to articulate by others which are deemed to be easier to articulated. Instances of substitution are italicized and the correct pronunciation is enclosed in brackets.

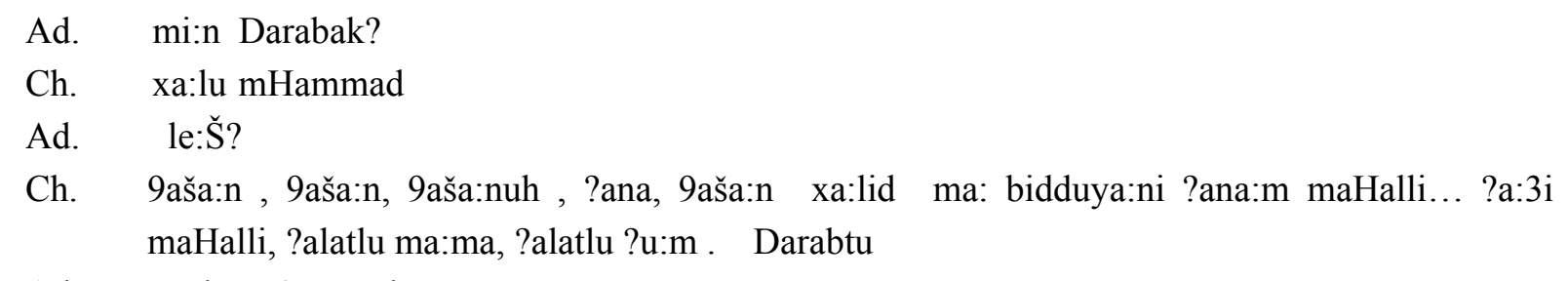

Ad. Darbatu 9aša:nak 
Ch: la? ?ilha ma:ma sa:9a bida:di (bitna:di) 9ale:h.

Ad. ?e:š bit?ullu?

Ch ?u bas bas

Ad šu bitsawwi?

Ch ?e:? baliffu

Ad le:h?

Ch. he:t (he:k).... baliffu

xa:tu (xa:ltu), ?aHti:lit (?aHki:lik) we:n iDDubbi:h?

Ad. we:n

Ch. fo:?,....fo:?......fo:?.......Ga:d

Ho:n...HaTTu: fo:? Xaz:nit ta:9it ta:9it te:ta

La? bidna nxalli:h ho:n ?aHsan

. $\quad$ aHti:lt (?aHti:lit) we:n tHuTTi:h.?

Ad. we:n?

Ch. HuTTi:, HuTTi: , ho:n, ho:n HuTTi:h

Ad šribt šai?

Ch la?

Ad ?adarsak?

Ch ?a:, xalaS, darsi:ni, darsi:ni, darsi:ni

Ad mi:n Darabak

Ch. 9a:mir

Ad we:n Darabak?

Ch. Darabni bilHad3ar, ilHad3ar tbi:r (kbi:r), miš zGi:r, tbi:r (kbi:r), he:t(he:k).

Ad. le:š ma Darabtu?

Ch. ?u ?anabarmi Hd3a:r zGi:re 9ad3a:mi9

?a: fi: walad bi9ayyiT, rame:t fu?i:h, ma: bi9ayyit

ha:da walad izGi:r , walla A19an ra:su, ?a:1 Darabni bHad3ar zGi:r,

laTaxni, walla, walla ma bakzib, walla ma bakzib

Ad wle:h ya HammU:dih. Tab ilwalad ?illi wa??afak bišša:ri9

Ch ?e: š?

Ad walla šuftak bišša:ri9

Ch. ?iHtI:lu ( ?iHki:lu) ha:da ?axu:y xa:lid, fa:him BaTTaxak taff...(kaff)

Ad kunt laHa:lak ma: ši fišša:ri9?

Ch kunt u xa:lid ?a:, ?axattu (?axadtu) ma9i hassa.

Ad la: ?ana, baHki 9an il9aSir, lamma ?ana ?ultlak ru:H ištri, 9asire:n

Ch. duzda:n mi:n hada:k... duzda:n mi:n?

Ad duzda:n xa:lu mHammad

Ch zay duzda:n ba:ba, zayyu walla, zay duzda:n ba:ba

bas šara wa:Had d3di:d

Ad šara wa:Had ddi:d?

Ch. bas Ge:r ha:d, bas Ge:ru, ya9ni zayyu

la?, ?awa3i:ti (?awa3i:ki) te:f(ke:f). 9aš:n til9abi, 9aš:n til9abi, 
Ad la:zim tit?akkad ?innu ha:d maHTu:T

Ch we:n?.. we:n ? we:n maHTu:T

Ad. kulhum maHtuTa:t xalaS, Tawwi:h, Tawwi:h

Ch. la?, la?, stannic ?awa33i:ti (ki), te:f $\{\mathrm{ke}: \mathrm{f})$ yiDwi

Ad. xalaS basai:h, xalaS hassa, ?ikbis, stanna.

Ch. ha:da ilmud3ad3il (lmusad3d3il)

Ad. Hammu:dih ma: bisawwi ma9 ?ummu he:k

Ch bisawwi.. walla bisawwi

Ad šuft ma: buzbuT

Ch. buzbuT buzbuT walla buzbuT ?awad3d3i:ti (ki), bištGil walla bištGil ild3iha:z

Ad ba:ba raHal, b:ba raHal

Ch he:t (he:k) walla., ma: biddu yi:d3i, bi:d3 bille:1, bille:l'

?a:h. ?i:di šal9atni, ?axawwiftu ( $k u)$ ?

Ad ?a:h, xarabi:š, xarabi:š, mi:n ?a:1 xarabi:š, xarabi:š, , nu:r?

Ch mi š xarabi:š, ?i:d SaH ?:d. walla ?inni ?ašTar minnit ( $i k$ ),

Ad. ?int 9ind mi:n bitruH t?uS ša9rak?

Ch. biwa??if, bwa??ifli ?iyya:h.. he:k

Ad. ?e:š bitHuTT 9ale:h?

Ch. $\quad$ 3ili u bimaššiTli ?iyya:h u biwa??ifli yya:h he:t.

Ad lamma tru:H 9al9urs?

Ch. $\quad$ la/.. bas.. la?, ?a:1 hadi:t (i:k) ilmarra fi: 9ina filmazra9a talb(kalb), ?a:l rani:m HaTTat Su:S 9ara:si

Ad. Su:S?

Ch. Su:S zGi:R, zGi:r

?a:h ya Hara:m ?abu:hum tbi:r (kbi:r), he:t (e:k) ?abu:hum he:t (he:k).

?a:h 9ine:h he:t (he:k)., ho:n 9e:n u ho:n 9e:n

Ad. le: š hu: Hurr, bixawwif.

Ch fibo:ti....?ana šalaHtu, šalaHtu, bo:ti 9aša:n a: yudxul fi: ?aza:z,... fi: ?aza:z filbo:t , ma:ma Gaslatu

Ad ?inte Gasalt mobile ba:ba

Ch la? xa:lid Gasalu miš ?ana

Ad ma:ma ?a:lat?nta

Ch. la?, la? miš ?ana

Ad šu bi9mal ha:d?

Ch. miš he:t (he:k)...zla:m he:t biSallu, ?allahu ?atbar (?akbar). ?aSalli 9an d3add? Walla baSalli.

Ad ?a:, Salli

Ch wHya:t ?alla šuft ab:uha

Ad mi:n?abuha

Ch ?iHna ra:yHi:n 9almazra9a....9almazra9a, ta:9itna

f:h d3amal 9ala ta:9itna, SaHH, d3amal 9ala ta:9itna,SaHH 
la?e:t Has:n zGi:r, ya Hara:m Has:n zGi:r. ruHna 9almaT9am. ruHna 9almaT9am. Šufti:na w?iHna firriHle. ?a:1 fi:h d3amal 9a:mil he:t $\{$ he:k)

btintiš fi da:nu, u 9ine:tu he:t (he:k). zayy il?ahbal he:t (he:k).

Ad rkibit alad3amal?

Ch rkibit ale:h. ma:ma rattabat (akkabat) 9ale:h xa:lid. Xa:lid 9ayyiT minnu

Ad le:š xa:f?

Ch walla xa:f

Ad kbi:rild3amal?

Ch tbi:r (kbi:r)

Ad ?e:mta bitru:H 9almaddrase?

Ch ?issane ild3ai

Ch ?a:

Ad ?e:š bitHuTTak

Ch. filmadrase, tamhi:di

Ad ?awa:9i mis raGad Hilwa:t?

Ch. la? bas Hilwa:t, hai hado:1, ma9 hai bas Hile, Hilwe, Hilwe bas Hilwe, ya rani:m ha:da, talafo:ni, ha:da talafo:n ba:ba, biddi ?a3ad3il So:Ti (?asad3d3il So:ti).

Ad. ?inte we:n ruHt, halla ?

Ch ho:n

Ad šu kunttsawwi? rudd9alayye?

?e: ̌ s ha:d?. btil9ab bilkumpju:ter ? mi:n li9ib fi:h?

Ch. xa:lid bil9ab fi:h, bille:l ,...?inti šufti:h?

Ad la?, ma: šuftu.

Ch. bitabbis, bitabbis (bikabbis), biDawwi:h, biTfi:h $x a: t u$ (xa:tu), biddi ?a19ab.

Ad we:n til9ab?

Ch fi yu:ter (yu:ter). ?a:, ‥ ?a: xall:ni ?al9ab fi:h. nil9ab šadde.

Ad šu štare:t?

Ch šare:t silte (silke), silte ta:9 3ali, u šibs, u basto:t (basko:t) u 9aSi:r .. u bas

Ad miš ?a3a walad biddu juDurbak?

Ch la? ma: ?a3a:ni

Ad ?ana šuftu

Ch. la? ?iti (?inti) tunti (kunti) na:ymih

Ad mba:riH ?ana šuftak

Ch la?

Ad walla,?ana šuftak

Ch la?

Ad ?e: š sawwa:lak ilwalad

Ch ?a:1, ?a:1 ?iti (?inti) šufti:ni.

Ad hiyye šafatni? xa:tu ha:la šafatni? le:š ma Drabtu u harabt?

Ch la> ma: Drabtu u harabt

Ad Tab le: š ma: Darabtu?

Ch ?i3a walad biddu yuDurbu., ?a: winti naymeh. 
Ad u ?e: ̌s sawwe:t ?inte?

Ch u te:ta ?alatli ?ištari silte (silke), u ?axade:t ma9i xa:lid

Ad na:m 9inna ya xa:ltu bas ma: t9ayyiT.

Ch walla bana:m laHa:li. wiHya:t ?alla

Ad biDDallak t9ayyiT

Ch la?

ha:da šilin

Ad hai šilin?

Ch le:a, hayha.. hai xams danani:r. walla btištari labab wixya:r u zazar (3azar).

Ad ?e: š bti9mal ya xa:tu?

Ch btuDrub ilwalad fišša:ri9

Ad mi:n sakkar 9ala ?i:dak ilba:b?

Ch bas ?umit ?asatru (?asakru) sattar (sakkar) 9ala ?i:di

Ad ?inte ma: šuftu?

Ch xa:lid SaHH, ?ana SaHH xabaTit fil3arra:r

Ad le: ̌̌ Darabt xa:lid?

Ch la? ma: Darabtu. ?axade:t minnu ? ššibis. Šibsi, šibsi

Ad ?e: š bti9rif tursum?

Ch ma: ba9rif .... bas badrus . ?aHti:ltu (?aHki:lku) ?ana baswiiltu(ku) yya:hum.

Ad ?inte ma: bti9rif til9ab?

Ch ba9rif. ?ana bafttiltu (ku), 9ašara, xamse, la? .. la? .. biddi ?a9idhum tulhum, (kulhum). ?arba9a... xamseh

Ad ?adde: š hadO:1?

Ch miyye... miyye... u 9ašara malyo:n, balyo:n... malyo:n

Ad ki:f ?al9ab ?iHki:li

$\mathrm{Ch} \quad$ xudi iššaddeh min xa:lid

Ad ?e: š bidna nil9ab?

Ch xalaS nil9ab šaddeh

Hammu:dih ma: bi9rif yil9ab šadde

Ad yalla bidna nfutt

Ch biddi: š ?a9Ti:ti itti:r (ikti:r\}

Ad ?ayy sa:9a Shi:t?

Ch ?issa:9a u rubi9

Ad šu sawwe:t?

Ch. hayyu hassa bitšufi

Ad Hammu:dih ?e: š bitHibb ta:kul?

Ch laHme

Ad mi:n labbasak ilbanTalo:n?

Ch ša?lu:b , ma:ma

Xa:lu ?usa:ma , hayyu that 9inna. ?a9Ti:ni wara?a u ?alam.

?inte ma bti9rif tursum

Ad ?e: š biddak tursum? 


\section{1) Macrothink}

Ch. ?apil, do:r

Ad ?inte ma: bti9rif tursum?

Ch walla ba9rif

Ad xalli ba:b y9almak karate:

Ch ?e: š marate:h? ?e: š ya9ni marate:h?

Ad 9aša:n tuDrub illi Darabak.

?e: š biddak tištaGil bas tikbar?

Ch. ?aštari:li ba:S u sayya:ra

Ad. ?e: š biddak ti9mal 9alba:S

Ch biddi ?aHammil fi:um, yazi:d u bašša:r u yazan, basu:? Fi:, u baHuTT fi: banzi:n zay ba:ba, r:H 9ala albanzi:n, biHuTT fi: banzi:n .. ba:ba .. biHuTT fi: banzi:n..... ?ilba:S ?ah.... ba:ba

Ad ?e: š biddatSi:r lamma tikbar?

Ch bawazzi9 be:D ?ilna. ?e:h bawazzi9 be:D . .. xa:fu minni ?il3a3a:t ?imba:riH. rni:m miš ho:n ma9na. ?a:h rani:m ta:nat (ka:nat) ma9na....SaH..SaH....ruHna 9a33a3a:t

Ad we:n kama:n

Ch bas ba:ba ma: ?axadna 9a33a3a:t., ma: wadda:na 9a3a:3a:t

Ad muš na:si, ?ana ma: ruHt. Rani:m ra:Hat

Ch Tab ?nta we:n ruHit

Bas ruht ma9 ba:ba 9almazra9a u basb, ma: ruHtv9a33a3a:

\section{Conversational Exchange (3)}

Participants in the exchange are two adult female friends (A, B and the child Issa).

A. halla?, ?e:š Hanballiš ni9mal?

B. ?iHna bas hai ilmuqiddime tab9itna

A. la?,?iHna ?ayy ?i ši.....? ?ana ma9 fikret ?innu ?ayy ?i ši buxTur fib a:Ina ni9malu Tawwa:li

B. ?aki:d

A. ?e:h, ya9ni.....xalli:ni bas 9ala ša:n ?iHna nrakkiz niqra?ha , winšu:f ?e:s ?iHna 9milna

B. Tayyib

A. lazim kama:n nfakkir bi š šukr, hado:1 la:zim kama:n nHuthum

B. halla ?iHna raH na9Ti šukirna u taqdI:rna laHada

A. ?aki:d.... ?ahli:na

B. ?ahli:na SaHH, ha, ha, ha, ?imba:riH ?i3u ?axadu:ni minil3a:mi9a bille:1

A. hiba, tGaddi:ni?

B. ?a:, Tab9an, Habibti

A. walla, 9an3add

B. u ruHit witGadde:t. Ta.bxi:n maTfiyye za:kye

A. Tabxi:n faSu:lya za:kye

B. La:, ?iHna Ta:bxi:n maTfiyye, bti9irfi ilmaTfiyye?

A. ?a:. hai Zahra blaban

B. bit3annin

?ana ?ayy ?i ši fi: zahra /uli:li, >u ?i9zmi:ni 9le:h,Tayyib 

A. $\quad$ la? bas ?ana ma baHibb izzahra kti:r
B. le:h?
A. ai izzahra blaban.....?ana ?illi 9allamtha lakull idda:r
B. la:
C. $\quad$ mi š 9a:rfi
?ana yumi:tha 9milt Tabxa ?e:h....HaTTe:t 3a:3 m?aTTa9 bSiniyye
A. ?aho
B. ?u HaTTe:t 9ulbit zahra, ?u HaTTe:t 9ale:ha THi:n....THInyye ya rabb
A. $\quad 3 a: 3$ ma9 iTTHiniyye
B. ?a: bas.... ?u ..>arnabi:t... HaTTe:t fo:?u..?ana baHibb il?arnabi:T kti:r, fardtha wa?ti:ha bSiniyye, wi9miltha bilfurn. Ti19it bi33annin.
A. bitHuTTu 9ale:ha THi:ne
B ?a:h bi33annin btiTla9

A. la: ?iHNa binHuTT Zahra...bni?li:ha blaban bidu:n Thi:niyye.

B. $\quad 9 a: d i ~ ? u$ mumkin bTan3ara mi š bSinyye

A. ?isma9i hai hai ya9ni raH ta:kli ?aSa:b9ik wara:ha

B. ?aki:d

A. la:, bamzaH š , hai we:n raH ta:kli ?aSa:b9ik wara:ha

B. ?aki:d

A. $\quad$ la:, 9an3add amzaH š , hai we:n.... ?e:h bitHutt zzahra blaban

A. we:n kunt ?inte?

Ch. 9ind mu:mu

A. šu 9milt?

Ch 19ibt

A. Šu ha:da ?illi ma9ak?

Ch, ?inte ma9ak tinte:n

Ad we:n kta:bak?

Ch barra

Ad ru:H 3i:bu

Ch biddi:s (biddi: $\check{\text { ś }}$ )

Ad. ?inte ma: bti9raf tiqra?

Ch ?inbala

Ad ?iqra? ?a šu:f?

Ch malik yawm iddi:n, ?iyya:k nabudu wa ?iyyaka nasta9i:n

fi ?i ši ta:ni

Ad wala ?i ši xalaS

Ch ?ale:f ba:, ta:, la?

Ad Tayyib, ru:H 3i:b likta:b

Ch ma: biddi

Ma: biddi >a3i:b kta:bi

Ad le: š?

Ch he:k 
Ad ?aSlan ?inte mu: ša:Tir

Ch ?inbala, hayni 3ibtu

Ad ha:t

Ch ya ma:ma xall:ni ?a:xdu

?ana ?aSlan ba:ba biddu ywaddi:n 9arrawDa

Ad la?, ?inte ma: fi:

Tab le: š HaTTe:t likta:b barra?

Ch ?ana Hurr

Ad ?e: $\breve{s}$

Ch ma: daxlik

Ad we:n yu:sif

Ch 9ind mu:mu laHa:lu

Ad le: š laHalu

Ch 9asa:n (9a ša:n) ba:ba w?ana

Ad le: š ma Dalle:tu ma9a:h

Ch li?annu OGi:r (zGi:r)

Ad šu 9am ta:kul?

?ana biddi minha

Ch ?e: š

Ad za:ki, ?akalt za:za

Ch šu kama:n?

Ch ?akalt ruzz

Ad ?e: š ?aktar ?i ši bitHibbu

Ch bi:tsa

Ad šu ?afTart ilyo:m?

Ch labane $\mathrm{u}(x u b 0)$ xubz u be:D

fTu:r za:ki za:ki

Ad šu ya(ni xubz bil?ingli:zi

Ch bred

Ad be:D?

Ch eg

Ad ša:Tir

We:n ruHt imba:riH

Ch 9a lu:na pa:rk

?ana ilyo:m ra:0a9t (ra:3a9t) kti:r

Ad le: š? le: šs?

Ch 9a ša:n ?ana mari:D. ma: bti9irfi?

Ad ma9 mi:n ruHt 9alaa lu:na pa:rk:?

Ch ma9 ba:ba

?aSlan ba:ba biHibni kti:r

Ad šu sawwe:u hna:k?

Ch biddi:s (biddi: š) ?aHki:lik. 9aša:n lu:na pa:rk mu: Hilwe. 
Ad laa, ?aHla minnak. L9ibtu biTTaba:t?

Ch $\quad$ xalaS ma: biddi ?a?u:1 ?iši.

Ad le: š

Ch za9la:n

Ad ta9ba:n?

Ch la? la? bas za9la:n mu:mu ?axad iTTa:be. u ?anabiddi ?aDurbu

Ad ki:f biddak tuDurbu?

Ch buk, buk, buks

Ad le: š

Ch ?ana za9la:n

Ad minnak u min mu:mu u minnik ?inte

?ana ma: sawwe:t ?iši

Ch ?aSlan ba:ba biddu yištri:li Taba:t kti:r

Ad ?inte bti9rif t9idd lal9ašara?

Ch wa:had tne:n xamse sitte sab9a 9asara (9ašara)

?ana ba9rif ?arsum

Ad ru:H 3i:b il?alam

šu ha:da ?illi rasamtu?

Ch ha:da da:?ira

Ad ?ana ša:yif xarabi: $\breve{s}$

Ch ?ana ma: baxarbis, ma: baxarbis, ma: baxarbis (biš)

Ad šu ha:d kama:n?

Ad ?arsumlak si:du? Bti9rif

Ch ?a:h

Ad SaHH, ?inte ma: 9indak masTara

Ch ?imbala 9indi

Ad ?inte ma: 9indak

Ch la? 9indi, we:n maOTartik (masTartik)

Ad mxabbaye

Ch le:s (le: $\breve{s}\}$

Ad 9aša:n ma: Di:9. la?e: š hiyye ilmasTara?

Ch 9aAa:n nmatTir (9aša:n nmasTir)

Ad. bti9rif itGnni?

Ch ?aGanni:lik ?e: ya sna:ni

Ma:ma ?axdatni u ra:Hat 9aTTabi:b, ma: wa33a9ni u ka:n laTi:f

Ad ?abadan ma: bninsa:h

Mi:n 9allamak hal?uGniye ilHilwe?

Ch 9ammu hisa:m (hiša:m)

Ad we:n ruHt imba:riH?

Ch 9ind mu:mu

?inti biddik DDAlli ho:n?

Ad šu lo:n hai issayya:ra? 
Ch ?aSfar

Ad šu ha:da illo:n

Ch ?aswad

Ad u ha:da

Ch ?aHmar

Ad ha:da bti9irfu?

Ch ha:da ?abyaD

Ad ?abyaD. la? mu: ?abyaD

$\mathrm{Ch}$ ?imbala

Ad la?, ha:da ?ismu rama:di,

Ch ya9ni zay il?ayaD.ma:ma ?e:s ha:da

Ad h:DA BLU:

Ch ?e:s ya9ni blu:?

Ad ya9ni ?azra?

?e: š biddak?

Ch binna nSaliH ilkumpju:tar

min wein ho:na

Ad he:k xarrabtu:

Ch ?utrki:h halla biGuzzik

?ikibsi, Tu:T, ho:n

Ad ma: štaGal, šaklu xarba:n

Ch la: mu: xarba:n, huwwe SalHa:n

Ad ?a: xarba:n, bas. Biddi ?aSalHu

xalaS, ?inte ?il9ab bilqiTa:r. >ilqiTa:r sari:9

la? swaj bati:? ma: maša šu ma:lu?

$\mathrm{Ch}$ ?ana ?ultillik ?innu baTi:?

Ad til9ab bissayya:ra?

Ch ?ana bamassi:ha \{bamašši:ha)

Ad mašši:ha 9ala il?arD

$\mathrm{Ch}$ ?ana lamma ?aru:H 9al madrase biddi ?arkab bilba: $\theta$

Ad biddak tru:H 9almadrase?

Ch ?a:h

Ad le: $\check{s}$

Ch he:k.

Ad Hilwe hiyye ilmadrase?

$\mathrm{Ch}$ ?a:

Ad ?e: ̌̌ fi:ha

Ch fi:ha ?awla:d u fi:ha miss u fi:ha marazi:H (mara3i:H).

Hadi:k ilmarra ruHna 9a Hadi:qit 9amra,?a:

Ad ?e: ̌s 9miltu?

Ch ?akalna sawirma (šawerma, ilyo:m ,ilyo:m ilyo:m.

Ad ?iw ?e; š kama:n?

Ch ?ana Hake:t 9ammu biddi ?asaHsil 
Ad riDi?

Ch ?a:, šuft walad zGi:r. ka:n binaTniT u bi9ayyiT

Ad le: š?

Ch ka:n xa:yif

Ad hiyye issuHse:le itxawwif?

Ch la? ?ana ma: xift wala šwayy

Ad willa le: š ilwalad ka:n i9ayyiT

Ch huwwe zGi:r

\section{Copyright Disclaimer}

Copyright reserved by the author(s).

This article is an open-access article distributed under the terms and conditions of the Creative Commons Attribution license (http://creativecommons.org/licenses/by/3.0/). 